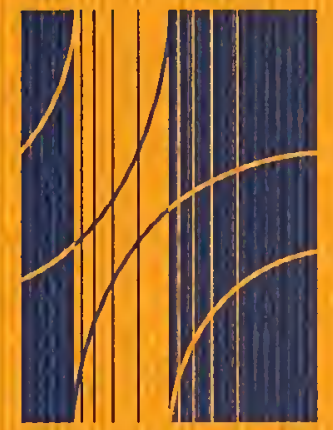

\title{
Joint
}

Transportation

Research

Program

J T R P

FHWA/N/JTRP-99/4

Final Report

EMBANKMIENT WIDENING DESIGN GUIDELINES AND CONSTRUCTION PROCEDURES

Richard J. Deschamps

Christopher S. Hynes

Philippe Bourdeau

September 1999

Indiana

Department

of Transportation

Purdue

University 



\begin{tabular}{l|l}
$\begin{array}{l}\text { 1. Report Na. } \\
\text { FHWA/IN/JTRP-99/4 }\end{array}$ & 2. Government Accesuion No. \\
\hline
\end{tabular}

4. Title and Subtitle

Embankment Widening Design Guidelines and Construction Procedures

3. Reciplent's Catalog No.

5. Report Date

September 1999

6. Performing Organization Code

8. Performing Organization Report No.

FHWA/IN/JTRP-99/4

Richard J. Deschamps, Christopher S. Hynes, and Philippe Bourdeau

10. Work Unit No.

9. Performing Organization Name and Addres

Joint Transportation Research Program

1284 Civil Engineering Building

Purdue University

West Lafayette, Indiana 47907-1284

12. Sponsoring Agency Name and Addres,

Indiana Department of Transportation

State Office Building

100 North Senate Avenue

Indianapolis, $\mathbb{N} 46204$

14. Sponsoring Agency Code

\section{Supplementory Notes}

Prepared in cooperation with the Indiana Department of Transportation and Federal Highway Administration.

\section{Abstract}

In recent years failures have occurred in Indiana highway embankments where the embankments were widened and steepened in order to facilitate construction of longer, safer acceleration and deceleration lanes and to increase the traffic capacity and efficiency of existing thoroughfares. The objectives of this study were to investigate the cause of failure and to make recommendations for modifying the existing INDOT Standard Specifications and construction guidelines in an attempt to avoid similar failures in the future.

A literature review and survey of state and federal transportation agencies was performed to collect current, available design guidelines and construction procedures for sideslope steepening projects. Several projects were investigated where widening and steepening of existing embankments was performed. Both failed and successful projects were investigated to discern the differences in approach used that may have led to failure in some cases. For each site, available design documents and construction records were reviewed to identify key aspects of individual projects that may have contributed to the projects being categorized as successful or unsuccessful. In general, very little information was available in terms of engineering design documents, field observations during construction, or as-built drawings for these projects. For the most part quality control tests were limited to the right-of-way with few tests conducted in the widened slopes.

Investigations of the failed embankments involved both field investigations and laboratory tests, including SPT and CPT tests, test pits, in situ density tests, index tests, compaction tests, and strength tests. Investigations of successful projects were also performed and included site reconnaissance and hand auger borings.

The results of the investigations indicate that failure of the widened embankments resulted from sub-standard compaction of fill and inadequate benching into the original embankment. Surface water infiltration from the roadway run-off contributed to the problem, possibly saturating and softening the soils. It is concluded that the slope failures investigated would not have occurred if INDOT Standard Specifications were followed during construction. Therefore, it appears that the primary cause of failure is the lack of appreciation of the potential risk by the parties involved. Several recommendations are provided to help prevent these types of failure in the future, including modifications to the existing specifications and the transfer of information among INDOT personnel

\section{Key Words}

soils, embankments, compaction, failure, widening, steepening, benching, curbing, compaction control.
18. Distribution Statement

No restrictions. This document is available to the public through the National Technical Information Service, Springfield, VA 22161
19. Security Classir. (of this report)

Unclassified
20. Security Classif. (of this page)

Unclassified
21. No. of Pages
22. Price 
Digitized by the Internet Archive in 2011 with funding from

LYRASIS members and Sloan Foundation; Indiana Department of Transportation 


\section{TABLE OF CONTENTS}

TABLE OF CONTENTS i

LIST OF TABLES iv

LIST OF FIGURES . v

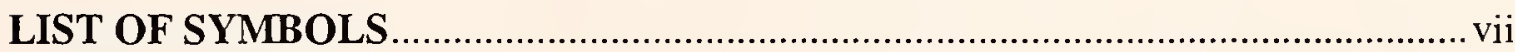

IMPLEMENTATION REPORT …..................................................................... vii

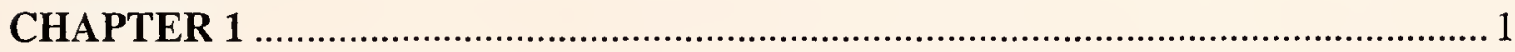

INTRODUCTION

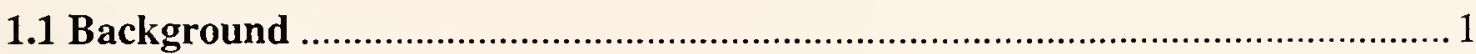

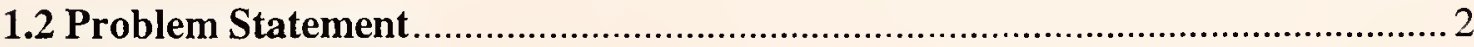

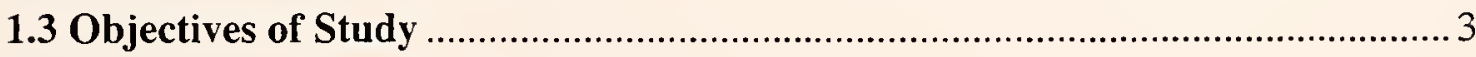

1.4 Project Approach ….......................................................................................

CHAPTER 2

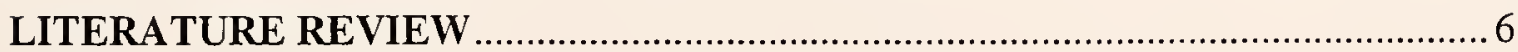

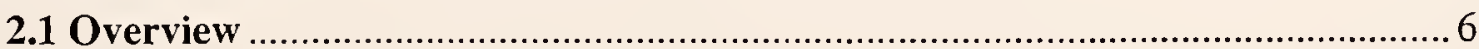

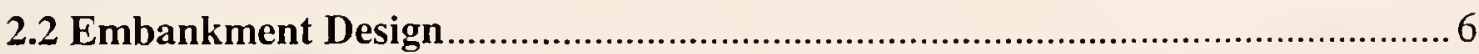

2.3 Surficial Stability ................................................................................... 8

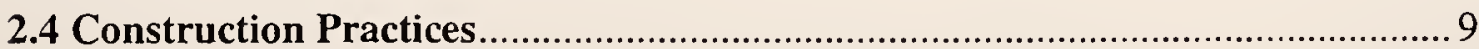


CHAPTER 3 12

EMBANKMENT WIDENING SURVEY 12

CHAPTER 4 14

SITE EVALUATIONS 14

4.1 Sites Evaluated 14

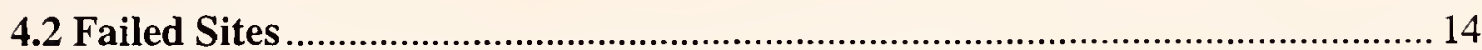

4.2.1 I-69, Madison Co., Greenfield District (R-20882) ........................................ 14

4.2.2 I-69, Grant Co., Fort Wayne District (R-19972) ........................................ 32

4.2.3 Calumet Avenue Interchange, Lake Co., LaPorte District (R-19181)........... 39

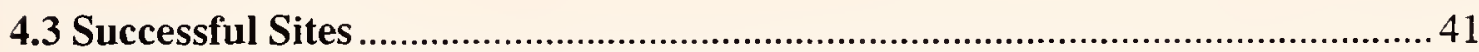

4.3.1 Wallen Road, Allen Co., Fort Wayne District (B-21135) ............................... 41

4.3.2 U.S. 421 Wanatah, LaPorte Co., LaPorte District (B-21433) ......................... 44

4.4. State Road 1, St. Leon, Dearborn Co., R-20879 …………………………....47

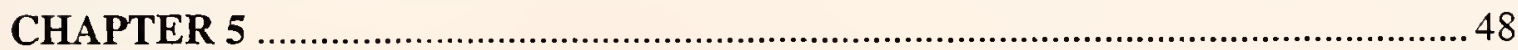

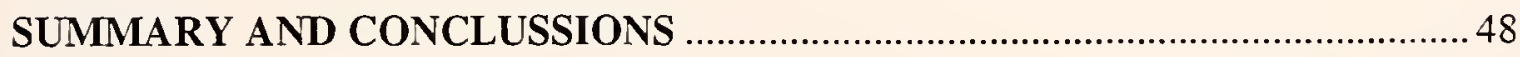

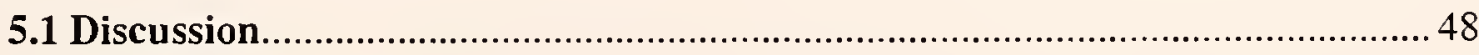

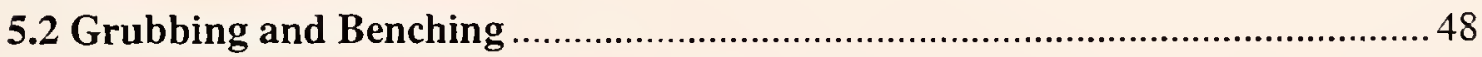

5.3 Compaction and Strength of Fill Soils ............................................................ 49

5.4 Compatibility in the Permeability of Fill Soils ................................................ 50

5.5 Controlling Surface Water Runoff .................................................................... 50

5.6 Considering the Presence and Flow of Groundwater within the Embankment52

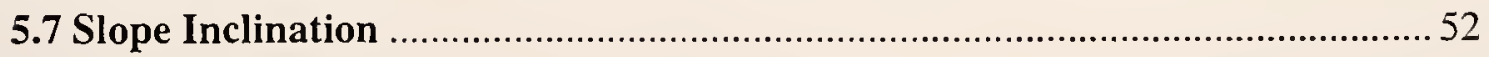

5.8 Recommended Changes to INDOT Standard Specifications ............................. 54 
5.9 Conclusions

CHAPTER 6

RECOMMENDATIONS

ACKNOWLEDGEMENTS .

REFERENCES 


\section{LIST OF TABLES}

Table 3.1. Summary of responses for embankment widening survey............................ 13

Table 4.1. Sideslope steepening project sites ................................................................. 16

Table 4.2. Field compaction test data for I-69, Madison Co. Greenfield District........... 17

Table 4.3. Laboratory strength test data, I-69, Madison Co., Greenfield District............22

Table 4.4. Standard Proctor test data, I-69, Madison Co., Greenfield District ................ 25

Table 4.5. Sand-cone test data, I-69, Madison Co., Greenfield District ..........................225

Table 4.6. Additional sand-cone test data, I-69, Madison Co., Greenfield District ........27

Table 4.7. Index test data, I-69, Grant County, Fort Wayne District ................................. 37

Table 4.8. Sand-cone and standard Proctor test data, I-69, Grant County, Fort Wayne

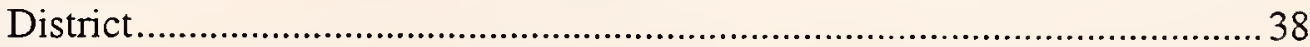

Table 4.9. Field compaction test data for Wallen Road Approaches, Allen Co., Fort

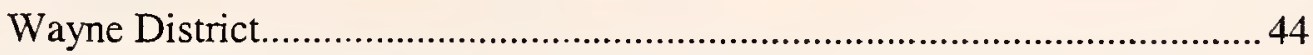

Table 4.10. Field compaction test data for U.S. 421 Wanatah, LaPorte Co., LaPorte District.

Table 5.1. Recommended slope inclination as a function of fill plasticity 54 


\section{LIST OF FIGURES}

Figure 2.1. Recommended method of benching (Indiana State Highway Commission 1971)

Figure 4.1. Site location map, I-69, Madison County, Greenfield District (Anderson South Quadrangle, Indiana) .................................................................. 15

Figure 4.2. Atterberg limits data, I-69, Madison County, Greenfield District............. 19

Figure 4.3. Activity of embankment soils, I-69, Madison County, Greenfield District

Figure 4.4. Standard penetration test data and water content profiles, I-69, Madison County, Greenfield District .

Figure 4.5. Cone penetrometer test data, CPT-710, Sta. $18+874$, O.S. $23.48 \mathrm{~m}$ 1t., I-69, Madison County, Greenfield District 23

Figure 4.6. Cone penetrometer test data, CPT-720, Sta. $18+838$, O.S. $21.34 \mathrm{~m}$ 1t., I-69, Madison County, Greenfield District

Figure 4.7. Standard Proctor test data and sand-cone data, I-69, Madison County, Greenfield District

Figure 4.8. Vertical deformation data, I-69, Madison County, Greenfield District..... 28

Figure 4.9. Horizontal deformation data, I-69, Madison County, Greenfield District 30

Figure 4.10. Site location map, I-69, Grant County, Fort Wayne District (Gas City Quadrangle, Indiana)

Figure 4.11. Standard penetration test data and water content profiles, I-69, Grant County, Fort Wayne District

Figure 4.12. Site location map, Calumet Avenue Interchange, Lake County, LaPorte District (Calumet City Quadrangle, Illinois-Indiana) 
Figure 4.13. Site location map, Wallen Road, Allen County, Fort Wayne District (Cedarville Quadrangle, Indiana). 44

Figure 4.14. Site location map, U.S. 421 Wanatah, LaPorte County, LaPorte District

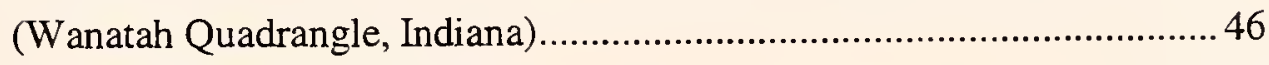

Figure 5.1. Schematic of Bench Inclination and Perforated Drain Placement .............51

Figure 5.2. Recommended Slope Inclination as a Function of Plasticity ...................53 


\section{LIST OF SYMBOLS}

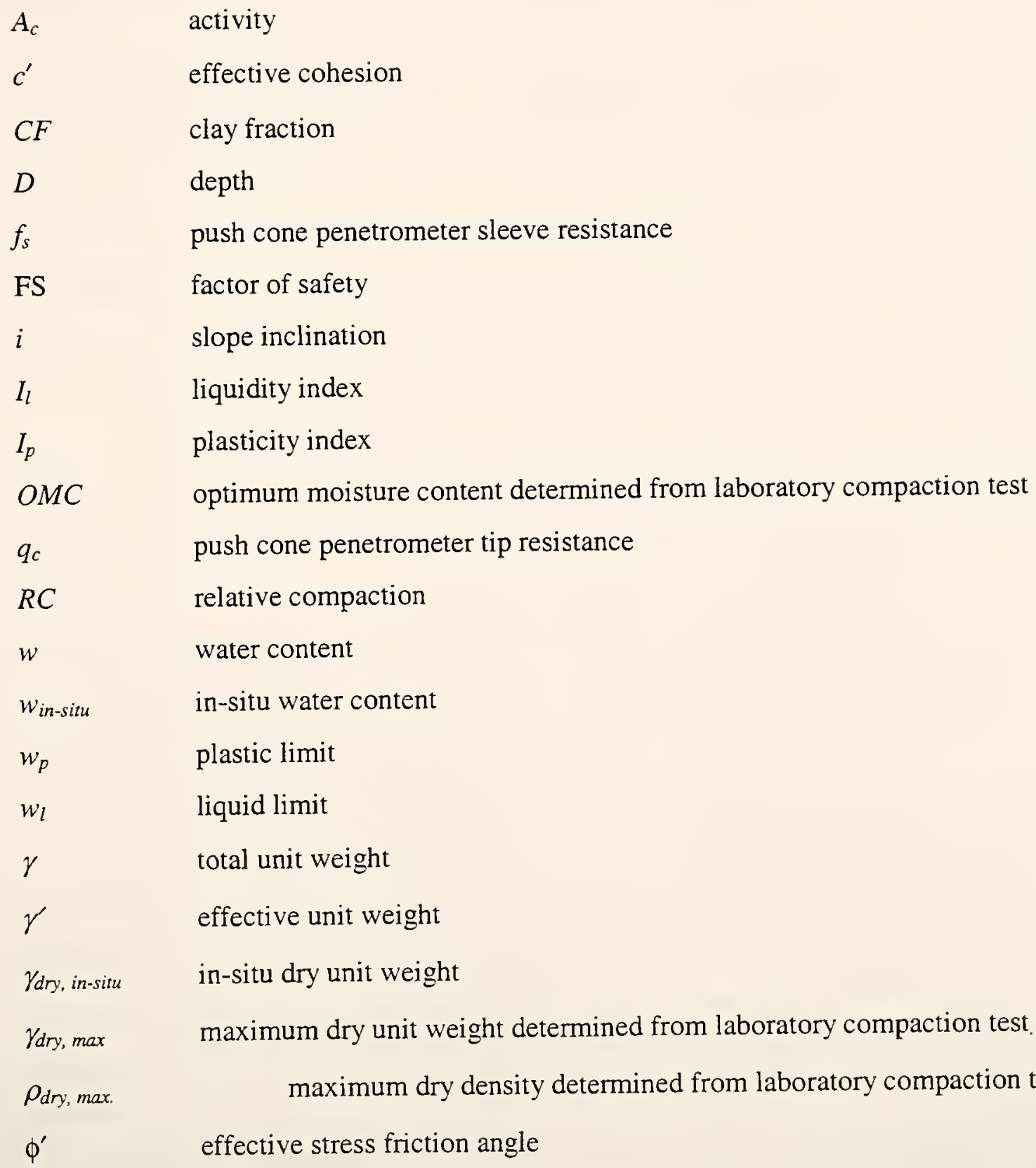




\section{IMPLEMENTATION REPORT}

Failures have occurred in Indiana highway embankments where the embankments were widened and steepened in order to facilitate construction of longer, safer acceleration and deceleration lanes, and to increase the traffic capacity and efficiency of existing thoroughfares. This study consisted of an investigation into the cause of these failures.

The results of the investigations indicate that failure of the widened embankments resulted from sub-standard compaction of fill, and inadequate benching into the original embankment. Surface water infiltration from the roadway run-off contributed to the problem, possibly saturating and softening the soils. It is concluded that the slope failures investigated would not have occurred if INDOT Standard Specifications were followed during construction, therefore, it appears that the primary cause of failure is the lack of appreciation of the potential risk by the parties involved.

Several recommendations are provided to help prevent these types of failure in the future. The recommendations can be grouped into three categories: 1) modifications to existing INDOT Standard Specifications; 2) improved project documentation and quality control practices; and 3) implementing a mechanism for communication among, and continuing technical education of, INDOT personnel. Suggested modifications to the INDOT Standard Specifications are made in this report. Implementation of a mechanism to address Items 2) and 3) is a greater challenge.

It appears that the failures occurred because the parties involved did not appreciate the potential for failure, that is both INDOT and contractor personnel. Construction supervision, documentation, and quality control testing were practically non-existent for the failed projects. Part of the problem may be that INDOT technical personnel responsible with the quality control of these projects are being spread too thin, that is a decision must be made as to what project, or what part of a project, requires priority attention.

If quality control personnel understood that the potential for failure was a reasonable risk then it is likely that the standard specifications would be enforced. 
Quality control personnel can become aware of the risk of failure by implementing an effective means of communication of failures across the INDOT districts, and by providing continued technical training.

The first recommendation is for the development of a technical newsletter that provides a short discussion of specific projects that encountered construction difficulties, failures, or innovative solutions. This newsletter would be distributed to the district engineers and construction technicians to improve the communication process and lower the risk of similar failures occurring in other districts.

It is also recommended that short courses be developed in which the technicians and district engineers can review specific technical topics. These short courses could cover a variety of topics and should be developed in concert with INDOT personnel to address specific priority needs. It is envisioned that a 2 or 3 day short course could be offered on a yearly basis during the winter months when it is easier to schedule around construction operations. The courses might be offered over a different period in three or four parts of the state to minimize travel and maximize scheduling. These short courses should be developed by persons with substantial design and construction experience.

It should be recognized that the costs associated with the implementation of a mechanism for communication among, and continued education of, technical personnel may appear significant. However, in many cases these costs would be offset by the avoiding failure of a single project where the cost of repairs can be much greater. 


\section{CHAPTER 1}

\section{INTRODUCTION}

\subsection{Background}

Existing highways in the State of Indiana are widened to facilitate construction of longer, safer acceleration and deceleration lanes, and to increase the traffic capacity and efficiency of existing thoroughfares. Highways on embankments require special consideration since the embankments are typically widened to increase the roadway width. Widening of embankments and highways is also employed on overpass approaches when bridges are widened. A number of technically sound solutions can be implemented to widen existing highways on embankments including:

- widening of the embankment while maintaining sideslope geometry;

- construction of retaining structures at the embankment toe and widening the crest;

- steepening of existing sideslopes while maintaining the toe; and,

- reinforcement and steepening of existing slopes while maintaining the toe.

Steepening of existing sideslopes while maintaining the toe has significant cost advantages over other methods:

- Additional right-of-way does not need to be obtained.

- Fill volumes are significantly less than if the entire embankment is widened while maintaining original sideslope geometry.

- Costly retaining structures which require periodic maintenance are not needed.

- Costly reinforcement is not necessary, and the associated inefficiency during construction is alleviated.

The Indiana Department of Transportation (INDOT) has successfully steepened sideslopes of existing highway embankments to widen roadways; however, a few failures have resulted. In certain instances, the failures were minor and limited to shallow sloughs on the steepened slopes. In cases where the distress was more severe, scarps were visible. In one case, failure in a steepened sideslope resulted in longitudinal cracks in the 
pavement and on the shoulder, requiring inconvenient lane closure and costly reconstruction of the embankment using reinforced soil.

Due to the costly nature of stabilization or reconstruction of previous failures, and INDOT's need for an economical means of widening existing highways on embankments, this research project was undertaken to identify the cause(s) of failure for three embankment widening projects in the State of Indiana, and to modify design and construction guidelines to be used for future projects. The focus of the study relates to failures in the compacted soils, not to cases where failures occur in weak foundation soils.

\subsection{Problem Statement}

Steepening the sideslopes of existing embankments to increase lane width or to add additional lanes poses technical problems for design engineers and practical, implementation problems for construction personnel.

Steepening of existing sideslopes by the design engineer reduces the margin of safety with respect to slope stability of an embankment. The designer must consider both the stability of the embankment, and the stability of the wedge of fill that is placed to widen the embankment. Preferential failure planes can develop at the interface between the original embankment and the fill placed to steepen the slope. Traditional stability analyses can be used to verify the stability of an embankment as a unit; however, these methods are not necessarily applicable for evaluating the stability of the wedge of fill placed on the sideslope.

Construction personnel are confronted with the practical problem of placing the additional earthfill on an existing slope. The work area available at the toe and crest of the highway is typically limited by site constraints, complicating placement of the fill. Traditional equipment may not be suitable for fill placement and compaction. The plans and specifications may not be sufficiently clear to convey the design engineer's intentions, and standard specifications on site preparation and fill placement may not adequately address and emphasize the importance of construction procedures utilized to construct the steeper slopes. In light of this, the characteristics of the steepened slope when constructed may not reflect the assumptions of the design engineer. 


\subsection{Objectives of Study}

The objectives of this study were to determine the cause of failure in recently widened and/or steepened embankments, and to develop design guidelines and improve construction specifications for use in the future. The proposed guidelines and modifications to the INDOT Standard Specifications were developed considering: previous experiences with sideslope steepening; the strength characteristics of compacted soils; conventional construction practices; and the limited availability of quality control/quality assurance personnel on most smaller sized projects.

\subsection{Project Approach}

A literature review and survey of State and Federal transportation agencies was performed to collect current, available design guidelines and construction procedures for sideslope steepening projects. The results of this survey are discussed in Chapter 3.

A total of six project sites were investigated. Five projects were evaluated where widening and steepening of existing embankments was performed. The projects evaluated were selected in concert with INDOT personnel who are knowledgeable of existing conditions at potential sites. The sixth site investigated was not a widened embankment. A failure occurred in a recently constructed highway embankment, and an investigation of the failure was made at the request of INDOT personnel. A short summary of this investigation is included in this report.

Two of the widened embankment projects can be categorized as unsuccessful. Unsuccessful sideslope steepening projects include projects where severe distress has occurred resulting in lane closure or damage to the highway and where costly repairs were required.

Two successful widened embankment projects were evaluated where the intent of the design has been achieved, and where distress has not occurred within the steepened, or widened, sideslope.

The fifth embankment widening project investigated was initially reported as a failed case, however, the site had already been modified to the point that an investigation could not be completed. A brief presentation was made at INDOT's annual technical 
retreat (Turkey Run, 1997) at which additional examples of failed sections were sought, however, no new failed sections were reported.

The initial step in project evaluation was the collection of available design documents and construction records for the selected projects. Review of this documentation was performed in an attempt to identify key aspects of individual projects that may have contributed to the projects being categorized as successful or unsuccessful. In general, very little information was available in terms of engineering design documents, field observations during construction, or as-built drawings for these projects. For the most part quality control tests were limited to the right-of-way with few tests conducted in the widened slopes.

Investigations of the unsuccessful projects involved standard, proven field investigation techniques and laboratory tests. Field tests included:

- Borings with standard penetration tests (SPT) to evaluate the stratigraphy and consistency of the fill.

- Cone penetration tests to evaluate the stratigraphy and consistency of the fill.

- Test pits to evaluate the stratigraphy of the fill and to collect samples for laboratory testing. Test pits were also useful for verifying or evaluating construction techniques including stripping, benching and compaction.

- In-place density testing utilizing a sand-cone to evaluate the in-situ density of the fill, and to permit characterization of strength based on in-situ densities for samples remolded in the lab.

Lab testing performed as part of the investigations included:

- Index testing for classification, and correlation to engineering parameters.

- Compaction testing to identify the moisture-density relationship for the soils investigated.

- Strength testing to evaluate the drained and undrained shear strength characteristics of the compacted soils. Testing was performed on remolded samples, acceptable quality undisturbed samples were not obtained. 
Investigations of successful projects were also performed. The in-situ densities and the shear strength characteristics of the compacted, sideslope fill were of particular interest. Information gathered from these projects is compared to that gathered from unsuccessful projects. 


\section{CHAPTER 2}

\section{LITERATURE REVIEW}

\subsection{Overview}

Methods for evaluating the stability of slopes, whether constructed or naturally occurring, are well documented (Bromhead 1986, Duncan et. al. 1987); however, little documentation exists regarding the stability of steepened sideslopes or sidehill fills. The parameters which determine the stability of steepened sideslopes are the same parameters which determine the stability of embankment sideslopes and naturally occurring slopes. Specifically, these parameters consist of the shear strength, unit weight, and stress history of the soil, and the slope geometry.

\subsection{Embankment Design}

Slope design for highway projects involves evaluating specific slope geometries that satisfy particular highway design requirements (e.g., right-of-way constraints, lane width requirements, etc.). Typically, detailed slope analysis and design is unwarranted, and the design engineer relies on previous experience for current design geometries. Where shallow slopes ( $<2 \mathrm{H}: 1 \mathrm{~V})$ are constructed, this practice is generally suitable; however, when embankments slopes exceed $2 \mathrm{H}: 1 \mathrm{~V}$, or only higher plasticity soils are available as fill, further analyses are warranted.

Methods specifically applicable to evaluating the stability of steepened slopes were not noted in the literature. Huang (1977) presented stability coefficients for sidehill benches. The coefficients are presented in chart form and are based on the Fellenius method of slices. Construction of benches in the existing slope is not considered, nor is the potential for preferential failure planes.

If the steepened slopes are considered as an integral part of the embankment, analyses for potential deep and shallow rupture surfaces can be performed. Either limit equilibrium or finite element analyses methods are applicable. Simplified charts, handcalculations, spreadsheets, or computer programs can be used for limit equilibrium analysis and should prove sufficient for most applications in Indiana. A concise summary 
of limit equilibrium and finite element analysis methods was recently presented by Duncan (1996).

Successful design of slope geometries is dependent on the appropriate selection of shear strength characteristics for the soils comprising the earth structure or slope. In addition, a thorough understanding of environmental factors which alter the shear strength of these soils over the design life of the structure is required. Leonards (1955) indicated that unless the shear strength characteristics of a soil over the design life of the structure are known results of stability analyses will be misleading.

Embankments and steepened sideslopes are typically constructed of compacted, cohesive soils in Indiana highway projects. Soils are compacted to improve their engineering properties, and this improvement is conveniently measured in terms of density and moisture content. Compaction decreases the permeability and compressibility, and typically increases the shear strength of soil. Since the stability of embankments and steepened sideslopes is a function of the shear strength of the soil, the importance of compaction is significant.

Classic, fundamental papers on compacted, cohesive soils have attributed the shear strength characteristics of these soils to clay and pore water chemistry, and fabric structure (Lambe 1958 and Seed et. al. 1959). Of particular importance to the designer or constructor, however, is the application of these fundamental concepts to everyday design and construction with earthen materials. These practical considerations with respect to undrained strength of compacted, cohesive soils were presented in detail by Leonards (1955), Lambe (1958), Seed et. al. (1959), and Casagrande et. al. (1962) and their immediate importance to the design of steepened slopes are as follows:

- An increase in the dry density of cohesive soils by compaction, at a constant water content, results in an increase in the undrained shear strength of the soil.

- The undrained shear strength of a compacted soil prepared at a constant density will typically decrease with increasing water content. The actual magnitude of this change is soil specific, and can only be verified by laboratory testing. 
Soils compacted dry of optimum water content tend to experience greater changes in density and strength with increases in water content that might be expected during the design life of the structure. When subjected to an increase in water content, soils compacted dry of optimum may swell at low confining stresses or collapse at high confining stresses. Moreover, soils compacted dry of optimum experience dramatic reductions in undrained shear strength with increases in water content. Soils compacted wet of optimum tend to display more axial shrinkage upon drying than soils compacted dry of optimum, however, this is rarely a concern for Indiana's climate once a vegetative cover has taken hold. The practical implications of these observations made from examining trends in laboratory data are useful tools for the design engineer.

\subsection{Surficial Stability}

Steepened slopes constructed of compacted, cohesive soils may also experience sloughing, the development of shallow failures with rupture zones parallel to the slope of the soil mass. Sloughing failures in compacted clays have been documented in Ohio (Wu et. al. 1993 ), and California (Day 1994). Lambe and Whitman (1969) indicate that this type of failure results from weathering of the surficial soil. Weathering weakens surficial soils, destroying most of its cohesion. The factor of safety for this condition can be analyzed using (eg. Day 1989):

$$
F S=\frac{c^{\prime}+\gamma^{\prime} D \cos ^{2} i \tan \phi^{\prime}}{\gamma D \sin i \cos i}
$$

The equation is derived assuming an infinite slope with seepage parallel to the slope to a depth, $D$. Day (1994) recommends selecting effective strength parameters for this analysis cautiously, indicating that effective strength parameters determined from strength tests performed at high confining pressures may not be appropriate. Triaxial strength tests performed at high confining pressures may over predict effective cohesion, resulting in misleading conclusions with respect to stability. Instead, Day recommends performing consolidated-undrained (CU) triaxial compression tests on compacted specimens at low confining pressures which model confining stresses representative of shallow depths on the slope. When modeling very small confinement, shear strength can be determined from unconfined compression tests on soaked samples (Day 1992). 
Based on experience gained in California, Day (1994) recommends the following for analysis of surficial stability:

- $\quad$ Determine appropriate depth of saturation zone, $\mathrm{D}$, based on local weather conditions.

- $\quad$ Prepare laboratory samples that reflect moisture content and density anticipated during field compaction.

- Analyze shear strength at low confining pressures, representative of field conditions

- Determine the factor of safety using equation 2.2.1. If the factor of safety is strongly dependent on effective cohesion or if the effective cohesion is greater than approximately $0.9 \mathrm{kPa}$, verify the effective cohesion using other methods.

In California the minimum recommended factor of safety is 1.5 for surficial slope stability (Dept. of the County Engineer 1978).

\subsection{Construction Practices}

INDOT (1993) Standard Specifications indicate that benching and compaction of soil used to construct embankments is required. Specifically, where an embankment is constructed on natural or filled slopes $4 \mathrm{H}: 1 \mathrm{~V}$ or steeper, benches are specified. The minimum width of the benches is $3 \mathrm{~m}$, unless otherwise indicated. Benching is further emphasized in the Indiana State Highway Commission's (1971) Road Design Manual, as presented in Figure 2.1.

The Standard Specifications indicate that embankment soils are to be compacted to $95 \%$ of the maximum dry density as determined by AASHTO T99 (Method A). The allowable moisture content range is -2 to +1 percentage point relative to the optimum moisture content $(O M C)$. The specifications also dictate that embankment material shall be placed in uniform level layers and that the lift thickness does not exceed 8 inches.

Appropriate construction practices are also presented in the Guide to Earthwork Construction (TRB 1990). The primary benefit of benching is that fill, when placed on a hillside or existing embankment, becomes keyed into the original soils. Benching also removes the potential failure surface that would be present between the fill and the 
original embankment, if benching was not performed. TRB recommends that benches be constructed where existing slopes are steeper than $3 \mathrm{H}: 1 \mathrm{~V}$, and that benches be constructed with a maximum height of 1.2 meters. 


\title{
FINAL REPORT
}

FHWA/IN/JHRP-99/4

\section{EMBANKMENT WIDENING \\ DESIGN GUIDELINES AND CONSTRUCTION PROCEDURES}

by

\author{
Richard J. Deschamps, Principal Investigator, \\ Christopher S. Hynes, Research Assistant, \\ and \\ Philippe Bourdeau, Principal Investigator \\ School of Civil Engineering \\ Purdue University \\ Joint Transportation Research Program \\ Project No.: C-36-36AA \\ File No.: 6-14-27 \\ Prepared in Cooperation with the \\ Indiana Department of Transportation and \\ the U.S. Department of Transportation \\ Federal Highway Administration
}

The contents of this report reflect the views of the authors who are responsible for the facts and accuracy of the data presented herein. The contents do not necessarily reflect the official views of or the policies of the funding agencies. The report does not constitute a standard, specification, or regulation.

Purdue University

West Lafayette, Indiana 47907

September 1999 


\section{TYPICAL METHOD OF BENCHING}
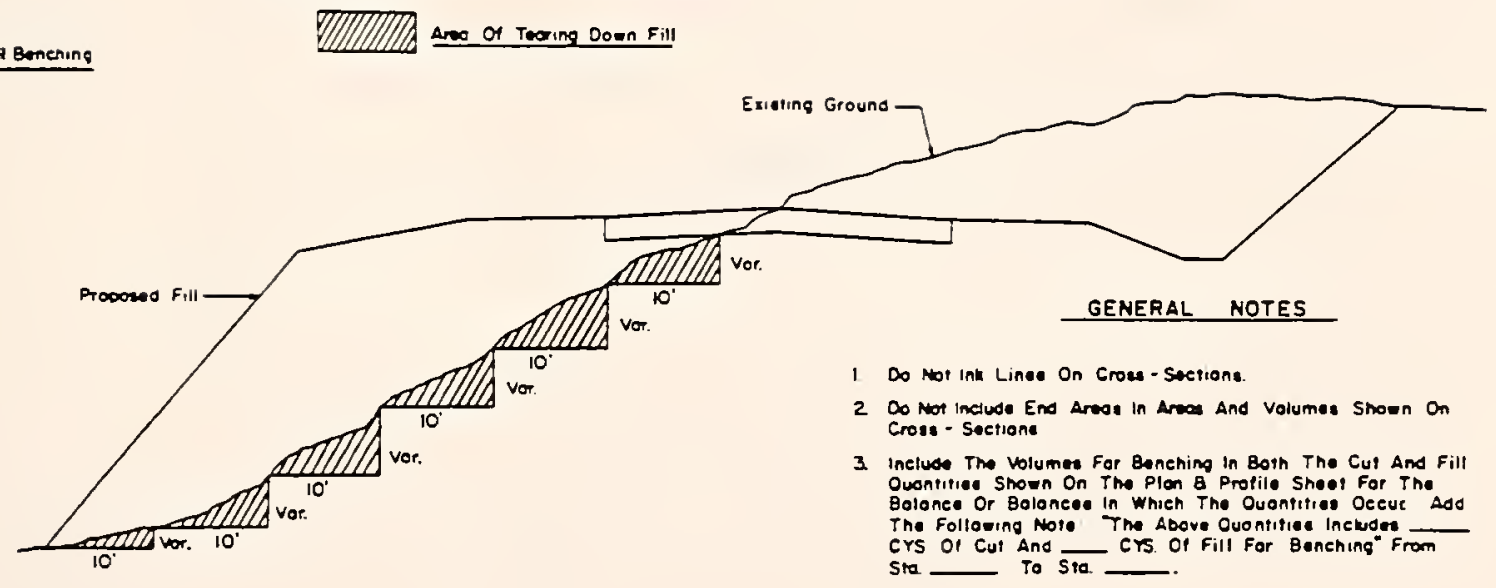

Figure 2.1. Recommended method of benching (Indiana State Highway Commission 1971). 


\section{CHAPTER 3}

\section{EMBANKMENT WIDENING SURVEY}

A survey of Federal and State transportation agencies was conducted. The goal of the survey was to obtain information regarding these agencies' experiences with steepening existing embankment sideslopes in an effort to widen existing highways. The findings of this survey are summarized in Table 3.1. The information provided by each transportation agency varied. This variation is attributed to:

- the differing geologic deposits in each state;

- the respective design and construction requirements established to construct on these deposits or to utilize these materials for construction;

- the perspective of the individual respondents (e.g., is their primary duty geotechnical or structural design, construction oversight, management, etc.); and,

- each respondents willingness to elaborate on their respective State's failures. Even with the variation in responses, certain trends were apparent regarding the construction of unreinforced embankments. These trends tend to indicate that the following is required for successful embankment widening:

- benching;

- compaction; and,

- drainage.

The use of select fills was not a primary concern of the respondents. The compatibility of the existing embankment soil with the new fill with respect to permeability was considered important. The survey results also indicate that unreinforced slopes up to $2: 1(\mathrm{H}: \mathrm{V})$ are typically used for highway embankments. No design documents or methodologies for design of unreinforced, steepened slopes were provided by the respondents. 
Table 3.1. Summary of responses for the embankment anden

\begin{tabular}{|c|c|}
\hline $\begin{array}{l}\text { Slote or Federal } \\
\text { Deparment }\end{array}$ & Comments \\
\hline \multicolumn{2}{|l|}{ Alsbarns DOT } \\
\hline \multicolumn{2}{|c|}{ Arkansas Sinle Highway \& Trans Depe } \\
\hline Califomus DOT & Office of Stroc \\
\hline \multicolumn{2}{|l|}{ Colorado DOT } \\
\hline Floridn DOT & Office of Strex: aturbured to hvdrosenic prescures \\
\hline Flonds DOT & Distria 1 \& 7 \\
\hline dahto Transportanion Deal & $x$ usmg remforcement + also faiked \\
\hline IOWE DOT & y case. \\
\hline Kansens DOT & Burcaus of Mer \\
\hline Kennucky Transporation Cabinet & Division of Mi 2:1. \\
\hline Marvland DOT & Materials \& Rac. \\
\hline Michigan DOT & Mareriais \& TSected $1: 1$ from shoutders and poor consoruction. \\
\hline Minnesols DOT & Consorucoon \&o sof foundation soils \\
\hline Nebrastes Depe of Roads & uet io $1: 3$. \\
\hline New Jersey DOT & e process of desiga thourth \\
\hline New York Stake DOT & Geolectureal Eo $1.5: 1$. \\
\hline North Carolina DOT & - \\
\hline \multicolumn{2}{|l|}{ North Carolins DOT } \\
\hline Ohio DOT & Office of Rand \\
\hline OTregon DOT & ensure stability. Planging to reifforee slopes seeper than $1.5: 1$ \\
\hline South Carolina DOT & yycare \\
\hline Texns DOT & Materiats \& Ts nents where fill hod $\mathrm{P} 1>30$. \\
\hline United Srates DOT - FHWA & Jy cace. \\
\hline United Stakes DOT - FHWA & Eastern Federe \\
\hline
\end{tabular}

Notes:

1. Specifications provided.

2 Design documents provided

3. Embankment steepening performed bus not for lnoe wideai

4. Cantilever walls, MSE walls, RE walks, gabion walls, $\infty$

5. Rock ubilized for embankment construetion or as surfece on 


\begin{tabular}{|c|c|c|c|c|c|c|c|c|c|c|c|c|}
\hline \multirow{2}{*}{$\begin{array}{l}\text { Sate or Federal } \\
\text { Departrent }\end{array}$} & \multirow{2}{*}{$\begin{array}{c}\text { Dimson, Unn } \\
\text { of Burrat }\end{array}$} & \multirow[t]{2}{*}{ Reppomeded } & \multicolumn{2}{|c|}{ 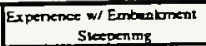 } & \multicolumn{2}{|c|}{ 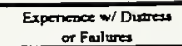 } & \multicolumn{2}{|c|}{ 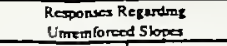 } & \multirow{2}{*}{$\begin{array}{c}\text { Uolue } \\
\text { Remplored } \\
\text { Slopes }\end{array}$} & \multicolumn{2}{|c|}{$\begin{array}{l}\text { Oune Methods } \\
\text { of Widening }\end{array}$} & \multirow[t]{2}{*}{ Comments } \\
\hline & & & Yes & $\frac{N o}{N o}$ & Ya & I vo & Slooct $1 \mathrm{H} \cdot \mathrm{V})$ & Bereching & & & Rock $k^{(3)}$ & \\
\hline Aibarama DOT. & & $x$ & $x$ & & $x$ & & & $x^{(1)}$ & & & & Failures noled in deco fills enthour benching \\
\hline 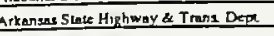 & & $x$ & $x^{01}$ & & & & & $x^{011}$ & $x$ & $\times$ & & \\
\hline califomun DOT & 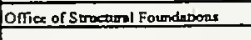 & $x^{x}$ & $x$ & & $x$ & & $1.5: 1(\max )$ & $x^{(1)}$ & $x$ & $x$ & & \\
\hline $\begin{array}{l}\text { Colorado DOT } \\
\text { Flonds DOT }\end{array}$ & 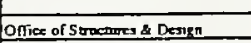 & & & & $x$ & & & & $x^{(1-2)}$ & & & 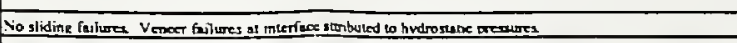 \\
\hline Fonds DOT & Distral 187 & $x$ & $x$ & & & 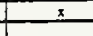 & $=\frac{1: 1(\max )}{1}$ & & & & & \\
\hline datho Trangportation Dege & & $\frac{x}{x}$ & $\frac{x}{x}$ & & $\frac{x}{x}$ & & & & & & & 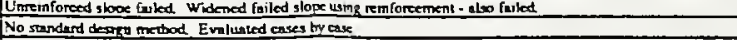 \\
\hline Lawa DOT & 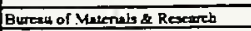 & $x_{-1}$ & & & & & & & $x$ & & $x$ & 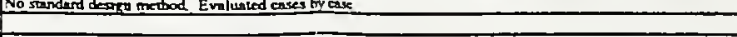 \\
\hline 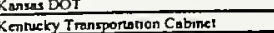 & Dimnoron of Mavenals & $x$ & $x$ & & $x$ & - & $3: 1(\max )$ & $x$ & & $x$ & & 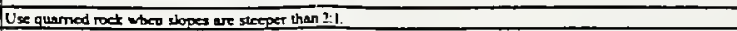 \\
\hline 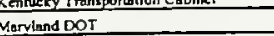 & Marmula \& Reactich & $x$ & $x$ & & $x$ & & & $x$ & $x^{(1,-2)}$ & & & 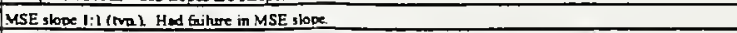 \\
\hline Miectugen DOT & 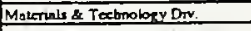 & $x$ & $x$ & & & & & $x$ & & & & 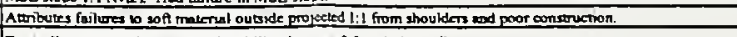 \\
\hline Mrnnceonats DOT & 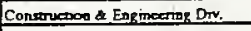 & $x$ & $x$ & & $-\frac{x}{1}$ & & 2:l(tipp) & $-x^{(1)}$ & $x$ & & $x$ & 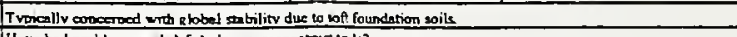 \\
\hline Nebraskn Dept of Roads & & & $x$ & & & & & & & $\times$ & & 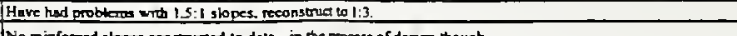 \\
\hline New Jersey DOT & & $x$ & 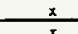 & & & & 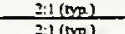 & $x^{(1)}$ & & $x$ & $x$ & 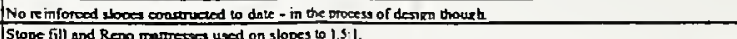 \\
\hline New York Stace DOT & 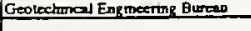 & $x$ & $x$ & & & & 2:1(10p) & $\frac{x}{x^{(1)}}$ & $\frac{x}{x}$ & $x$ & $-x$ & 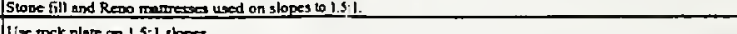 \\
\hline North Canolina DOT & & $\frac{x}{x}$ & $\frac{x}{x}$ & & & & $\frac{3: 1(100)}{2: 1(0,0)}$ & & $\frac{x}{x}$ & $x$ & $\frac{x}{x}$ & 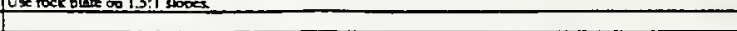 \\
\hline 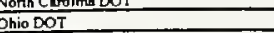 & DFfice of Rod dway Engrmectms & $x$ & & & 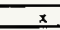 & & & & $x$ & & & \\
\hline OTeson DOT & & $x$ & $x$ & & $x$ & & $2: 1 \cdot 1.5 \cdot 1(\mathrm{~m} 2 \mathrm{x})$ & & $\pi$ & & & 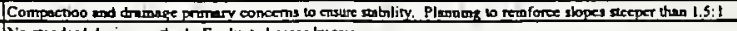 \\
\hline South Carolins DOT & & 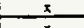 & & & & & & & $x$ & & & 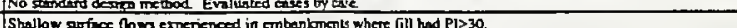 \\
\hline Tenas DOT & 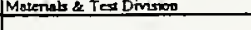 & $-\frac{x}{x}$ & $x$ & & $x$ & & & & $x$ & $x$ & & 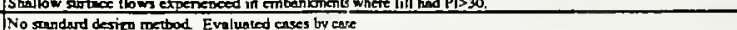 \\
\hline Uniled Snnce, DOT - FHWA & Easterm Foderal Lands Highwav Div & $x$ & & $x$ & & & & $x^{(3)}$ & & & & 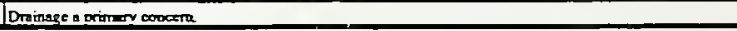 \\
\hline
\end{tabular}

Easem Foderal Londs Highwav Dir

Nouses:

1. Specificanoss provided

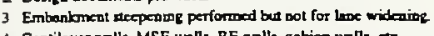

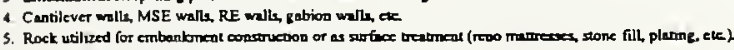




\section{CHAPTER 4}

\section{SITE EVALUATIONS}

\subsection{Sites Evaluated}

Five sites where embankment widening was performed through steepening of sideslopes were selected for evaluation. Two of the sites are considered successful projects and three of the sites selected displayed distress. One of the "failed" sites could not be fully investigated because conditions at the site were altered since the distress occurred. The location of each of these sites, extent of distress, and a brief description of each project is presented in Table 4.1.

Documentation pertaining to the design and construction of these projects was obtained from INDOT. Documentation obtained included site investigation records, design plans, and construction records.

\subsection{Failed Sites}

\subsubsection{I-69, Madison Co., Greenfield District (R-20882)}

Contract No. R-20882 was let on May 14, 1994. The project involved reconstruction of I- 69 between RP $22+96$ to RP $27+80$. Work under this contract included steepening the sideslope of the existing embankment. The embankment was widened from approximately Sta. 448+80 (PR-1), west of the bridge carrying I-69 over old SR 109 to Sta. $466+80$, west of southbound entrance ramp at Exit 26. The extent of the widening project and the site location is presented in Figure 4.1. The embankment widening was performed to increase the length of the southbound entrance ramp acceleration lane. The maximum increase in width was $12 \mathrm{feet}$, and the toe of the slope remained unchanged. Plans indicated that the maximum sideslope when regraded should be $2 \mathrm{H}: 1 \mathrm{~V}$. 


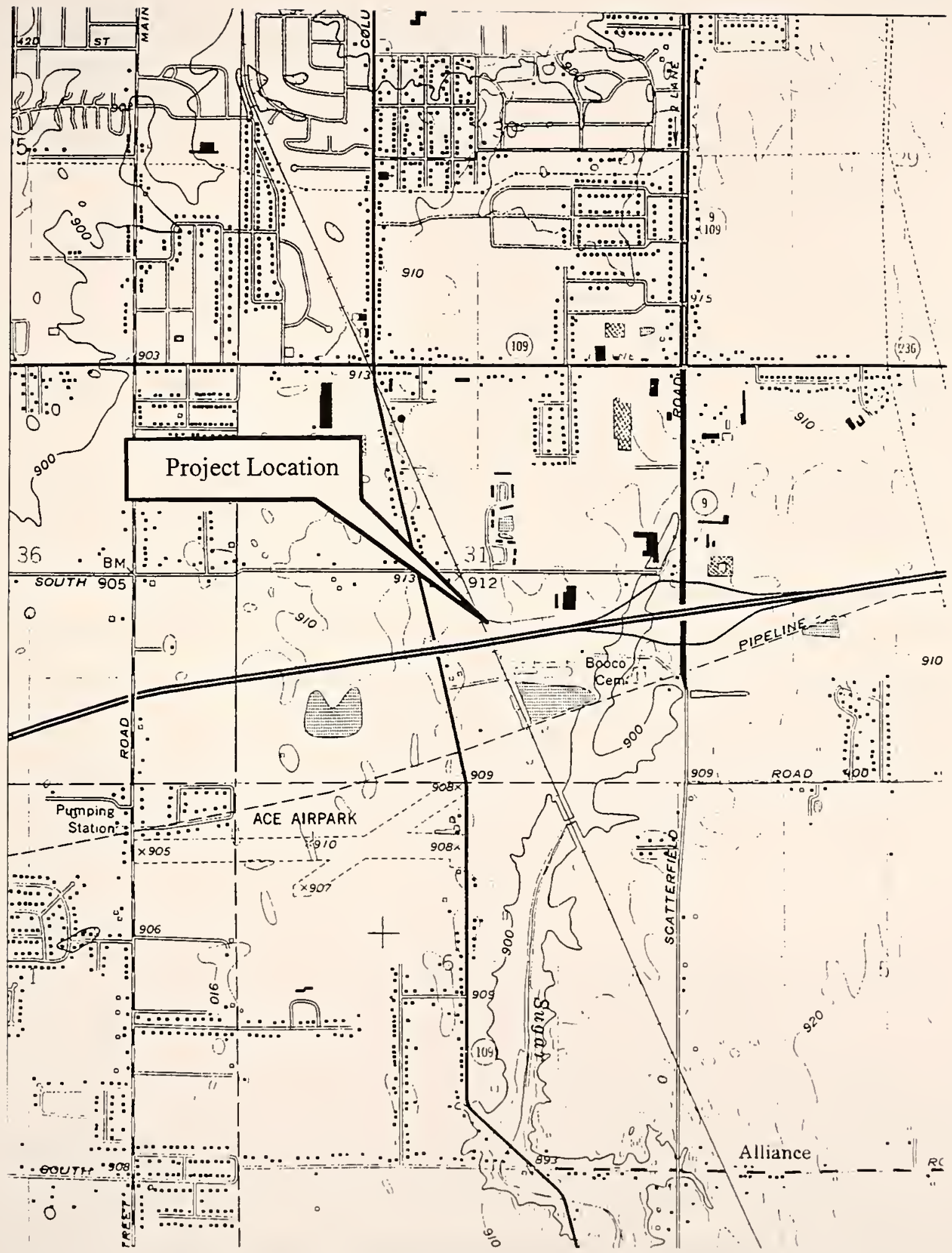

Figure 4.1. Site location map, I-69, Madison County, Greenfield District (Anderson South Quadrangle, Indiana) 
Table 4.1. Sideslope steepening project sites.

\begin{tabular}{|c|c|c|c|c|}
\hline County & District & $\begin{array}{c}\text { Contract } \\
\text { No. }\end{array}$ & Project Type & Comments \\
\hline Madison & Greenfield & R-20882 & $\begin{array}{l}\text { Extension of } \\
\text { acceleration lane } \\
\text { during roadway } \\
\text { reconstruction. }\end{array}$ & $\begin{array}{l}\text { Significant failure, resulted } \\
\text { in longitudinal cracks on } \\
\text { shoulder, settlement and } \\
\text { lane closure. }\end{array}$ \\
\hline Grant & Fort Wayne & R-19972 & $\begin{array}{l}\text { Extension of } \\
\text { acceleration lane } \\
\text { during roadway } \\
\text { reconstruction. }\end{array}$ & $\begin{array}{l}\text { Significant failure with an } \\
\text { approximately } 350 \text { foot } \\
\text { long scarp, serious erosion } \\
\text { subsequent to failure. }\end{array}$ \\
\hline Lake & LaPorte & R-19181 & $\begin{array}{l}\text { Interchange } \\
\text { reconstruction and } \\
\text { interstate widening. }\end{array}$ & $\begin{array}{l}\text { Shallow sloughs with no } \\
\text { damage to roadway. }\end{array}$ \\
\hline Allen & Fort Wayne & B-21135 & Overpass widening. & Successfully completed. \\
\hline LaPorte & LaPorte & B-21433 & Overpass widening. & Successfully completed. \\
\hline
\end{tabular}

Subsequent to roadway reconstruction distress was noted on the steepened sideslopes. Deformation was severe between Sta. $451+87$ and Sta. $457+48$ (i.e., between the bridges over Conrail and old SR 109) and longitudinal cracking along the shoulder of the road and in the pavement was noted followed by settlement of the shoulder. Repair of the section of roadway effected was attempted and additional asphaltic pavement was placed to true and level the roadway surface. Settlement continued, however, and it appeared as though the sideslope fill had failed.

\section{Embankment Design and Construction Plans}

Design documents were not available for the sideslope steepening project; thus, implying that stability of the steepened embankment was not analyzed prior to construction. The construction plans did not adequately address the embankment widening. Sections for the proposed widening were not provided in the plans. The plans indicated that the roadway was widened 3.65 meters and the maximum sideslope permitted was $2 \mathrm{H}: 1 \mathrm{~V}$. The original sideslope, however, appears to have been at an inclination of $2 \mathrm{H}: 1 \mathrm{~V}$ prior to embankment steepening. Slopes ended up being steepened to as much as $1.4 \mathrm{H}: 1 \mathrm{~V}$ at bridge cones, and to $1.6 \mathrm{H}: 1 \mathrm{~V}$ on average along the embankment. 


\section{Construction Records}

As-built plans for this project could not be located. Field compaction data was provided by the District and is summarized in Table 4.2. The nine tests indicate that the soil was compacted to densities greater than the minimum specified density of $95 \%$ of the maximum dry density as determined from the standard Proctor test (AASHTO T99, Method A). However, none of the tests performed lie within the steepened sideslopes. The offset is referenced to PR-1, the centerline for the project. The interface between the existing embankment and the wedge of fill placed to steepen the sideslope lies 60 feet left of the centerline. This appears to indicate that the tests in Table 4.2 were performed for the subgrade soils or base courses. The absence of compaction data for the sideslopes suggests that no compaction tests were performed on material placed to steepen the sideslopes.

Table 4.2. Field compaction test data for I-69, Madison Co. Greenfield District.

\begin{tabular}{lllllll}
\hline $\begin{array}{c}\text { Test } \\
\text { No. }\end{array}$ & Date & Station (ft) & Offset (ft) & $\begin{array}{c}\gamma_{\text {dry, in-sizu }} \\
\left(\mathrm{kg} / \mathrm{m}^{3}\right)\end{array}$ & $\begin{array}{c}w_{\text {in-situ }} \\
(\%)\end{array}$ & $R C(\%)^{(2)}$ \\
\hline $61(\mathrm{~S})$ & $8 / 15 / 94$ & $461+50$ & $24^{(3)}$ & 2228 & 3.6 & 111.1 \\
$72(\mathrm{~S})$ & $8 / 16 / 94$ & $455+10$ & $48 \mathrm{LT}$ & 2177 & 6.9 & 108.5 \\
$(\mathrm{~S})$ & $8 / 17 / 94$ & $461+70$ & $29 \mathrm{LT}$ & 1955 & 5.4 & 97.4 \\
$(\mathrm{~S})$ & $8 / 17 / 94$ & $461+50$ & $24 \mathrm{LT}$ & 2097 & 5.1 & 104.5 \\
$(\mathrm{~S})$ & $8 / 17 / 94$ & $461+60$ & $19 \mathrm{LT}$ & 1991 & 6.7 & 99.2 \\
$1(\mathrm{~S})$ & $8 / 19 / 94$ & $449+70$ & $25 \mathrm{RT}$ & 2080 & 8.7 & 103.6 \\
$2(\mathrm{~S})$ & $8 / 19 / 94$ & $456+00$ & $27 \mathrm{RT}$ & 1969 & 8.6 & 98.1 \\
$3(\mathrm{~S})$ & $8 / 19 / 94$ & $452+25$ & $24 \mathrm{RT}$ & 2037 & 9.0 & 101.5 \\
$(\mathrm{~S})$ & $9 / 23 / 94$ & $467+15$ & $16 \mathrm{LT}$ & 2319 & 2.2 & 115.6 \\
\hline
\end{tabular}

Notes: (1) Letter following test number indicates whether the density was determined using a sand-cone (S) or nuclear density gauge $(\mathrm{N})$.

(2) Relative compaction is equal to the field dry density divided by the maximum dry density for the soil.

(3) Direction of offset was not indicated in the original project documents reviewed. 


\section{Post-Failure Investigation Data}

A post-failure investigation was performed by INDOT. The field work was performed between December 1994 and March 1995. As part of this investigation seven borings were advanced and split-barrel samples were collected. Index tests, including grain size distribution, hydrometer and Atterberg limits analyses were performed on select split-barrel samples. The index test data has been summarized in Figures 4.2 and 4.3. As indicated by the index test data, the soils in the original embankment and those used to steepen the sideslopes are primarily low plasticity, fine grained soils, classified as $\mathrm{CL}$ in accordance with the Unified Soil Classification System . The activity, $A$, of these soils is approximately 0.75 on average, indicating that illite is the primary clay mineral.

The SPT data and moisture content profiles for the borings are presented in Figure 4.4. The estimated maximum depth of fill placed to widen the embankment is indicated on the profiles and is based on sideslope geometry. SPT data indicates that fill soils beneath the pavement are generally loose to medium dense (B-1 and B-5) or medium stiff (B-3). On the sideslope (B-10 and B-11), surficial soils are very loose or very soft; the consistency or density of these soils has likely been altered by the slide, and by surface water infiltration. With increasing depth, the embankment soils becomes stiff.

Density tests were performed on select split-barrel and undisturbed tube samples. Dry densities ranged from 1580 to $2133 \mathrm{~kg} / \mathrm{m}^{3}\left(98.6\right.$ to $\left.133.1 \mathrm{lb} / \mathrm{ft}^{3}\right)$ for the soils analyzed. However, the data is not reflective of the density of the fill placed in the sideslope during steepening. The densities reported by INDOT primarily reflect the density of naturally deposited soils at the toe of the slope or the density of the soils comprising the original embankment.

INDOT contracted Earth Exploration of Indianapolis, Indiana to perform three additional borings at the toe of the embankment, and perform consolidated, undrained (CU) triaxial tests with pore pressure measurements on remolded and undisturbed specimens. This sampling and testing program was undertaken to establish design parameters for slope stabilization. Laboratory strength test data is summarized in Table 4.3. 


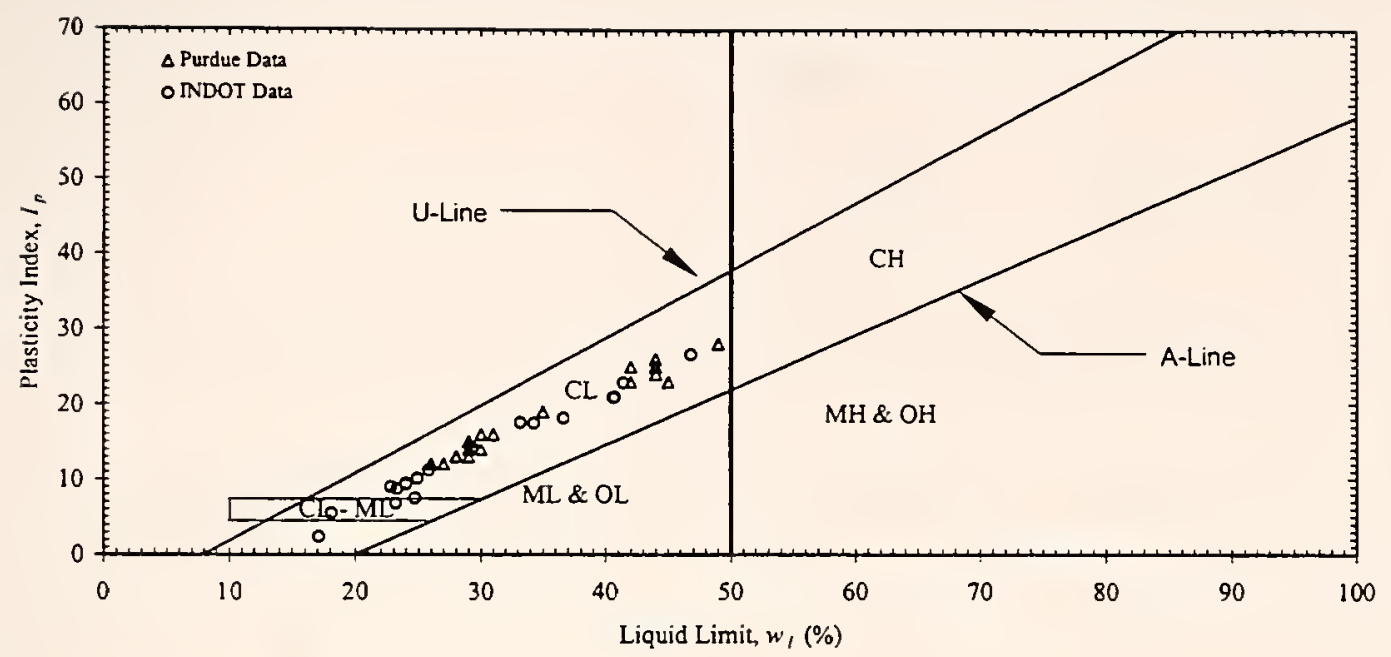

Figure 4.2. Atterberg limits data, I-69, Madison County, Greenfield District.

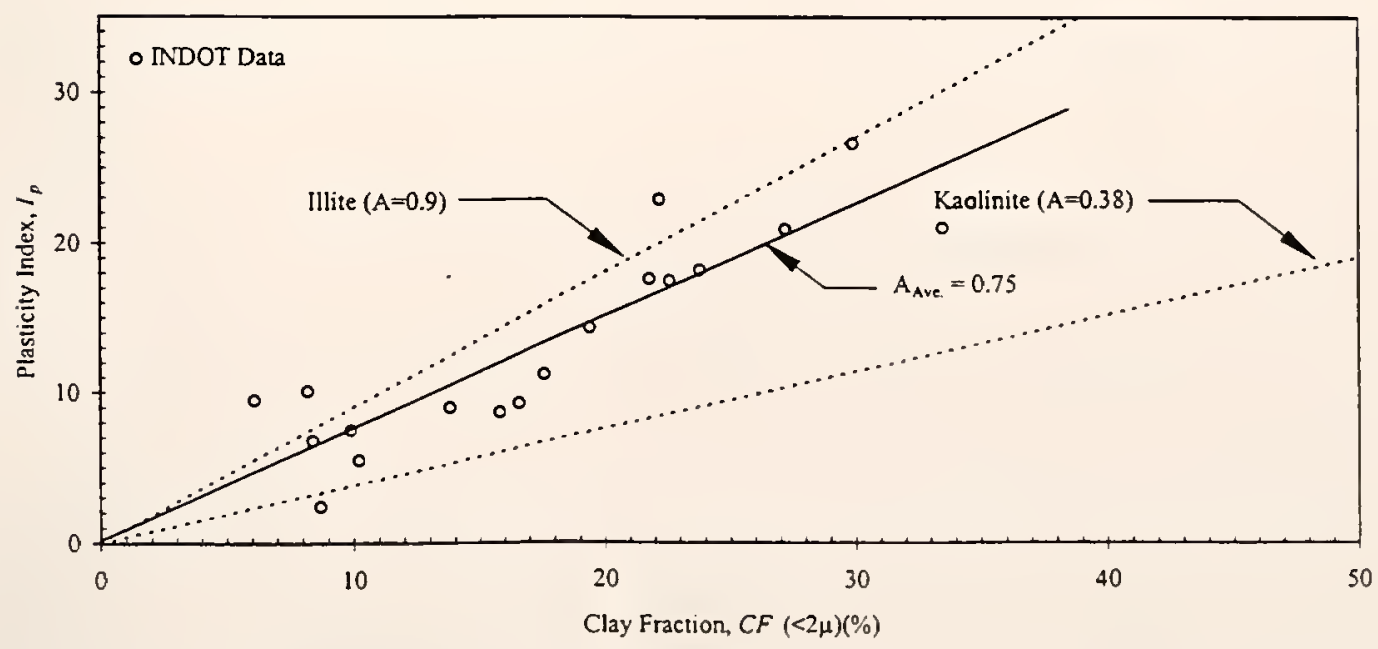

Figure 4.3. Activity of embankment soils, I-69, Madison County, Greenfield District. 


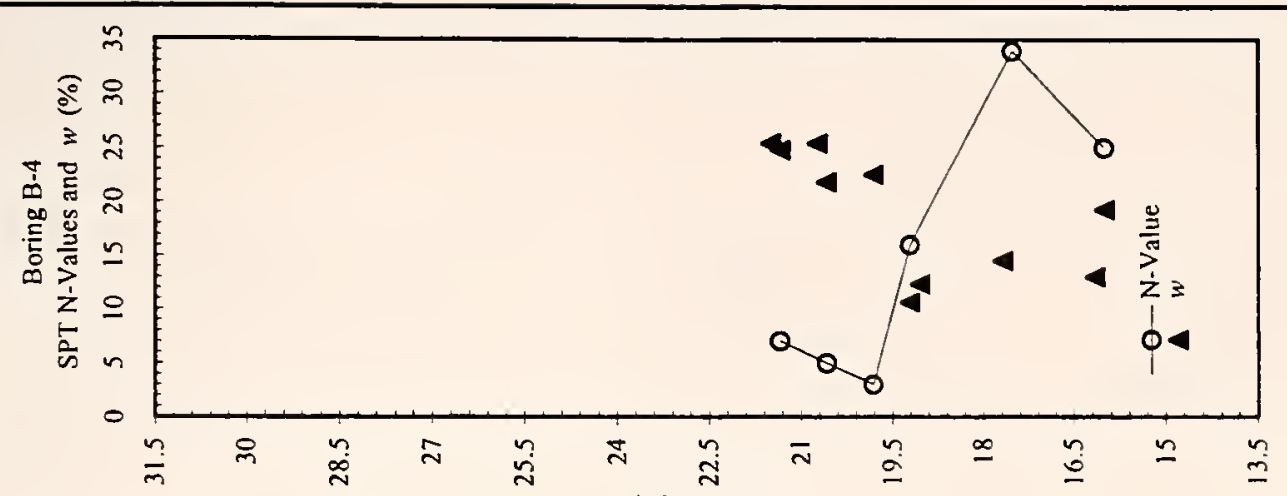

(ய) นоำงว!ี

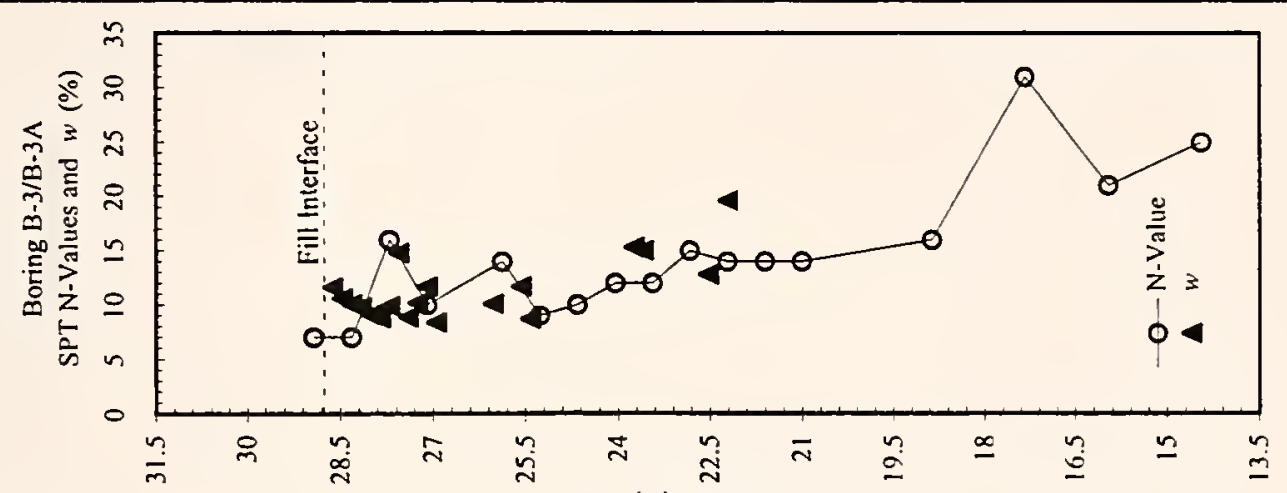

(w) บоำองวเอ

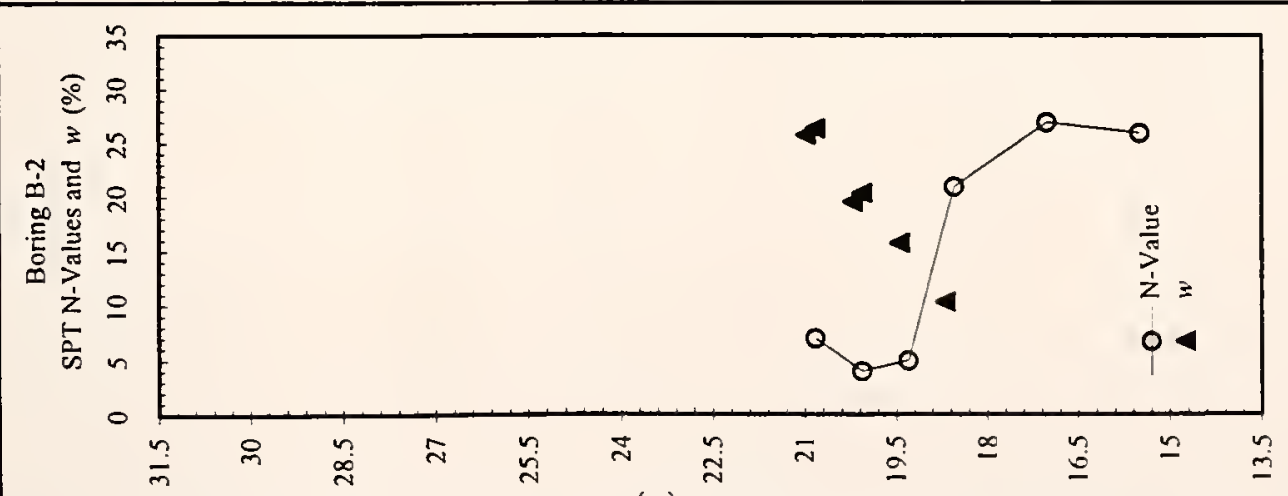

(w) นоำควอ

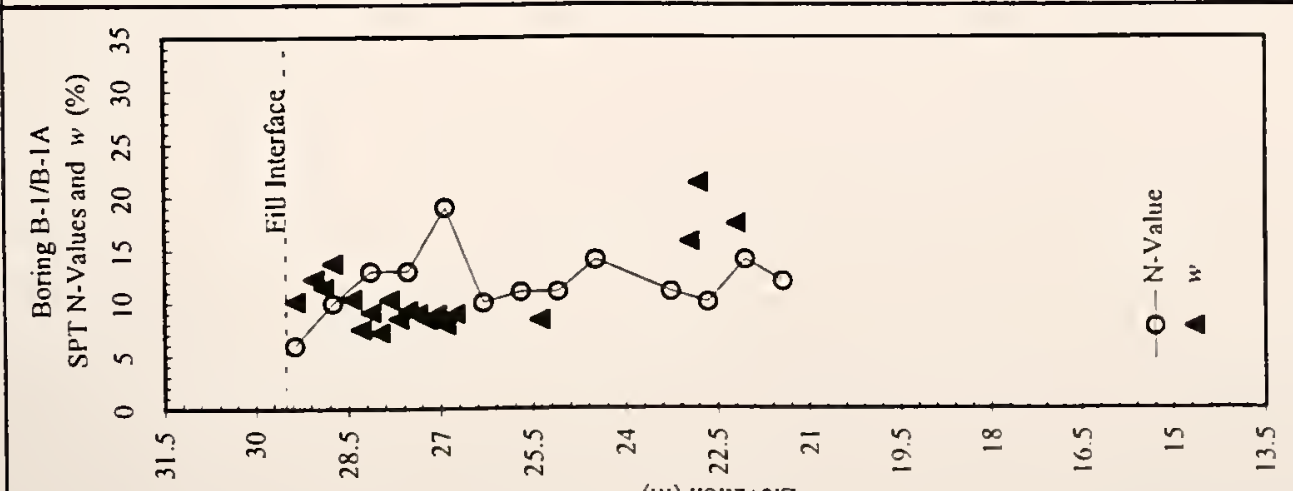

(u) นO!IEヘગヨ 


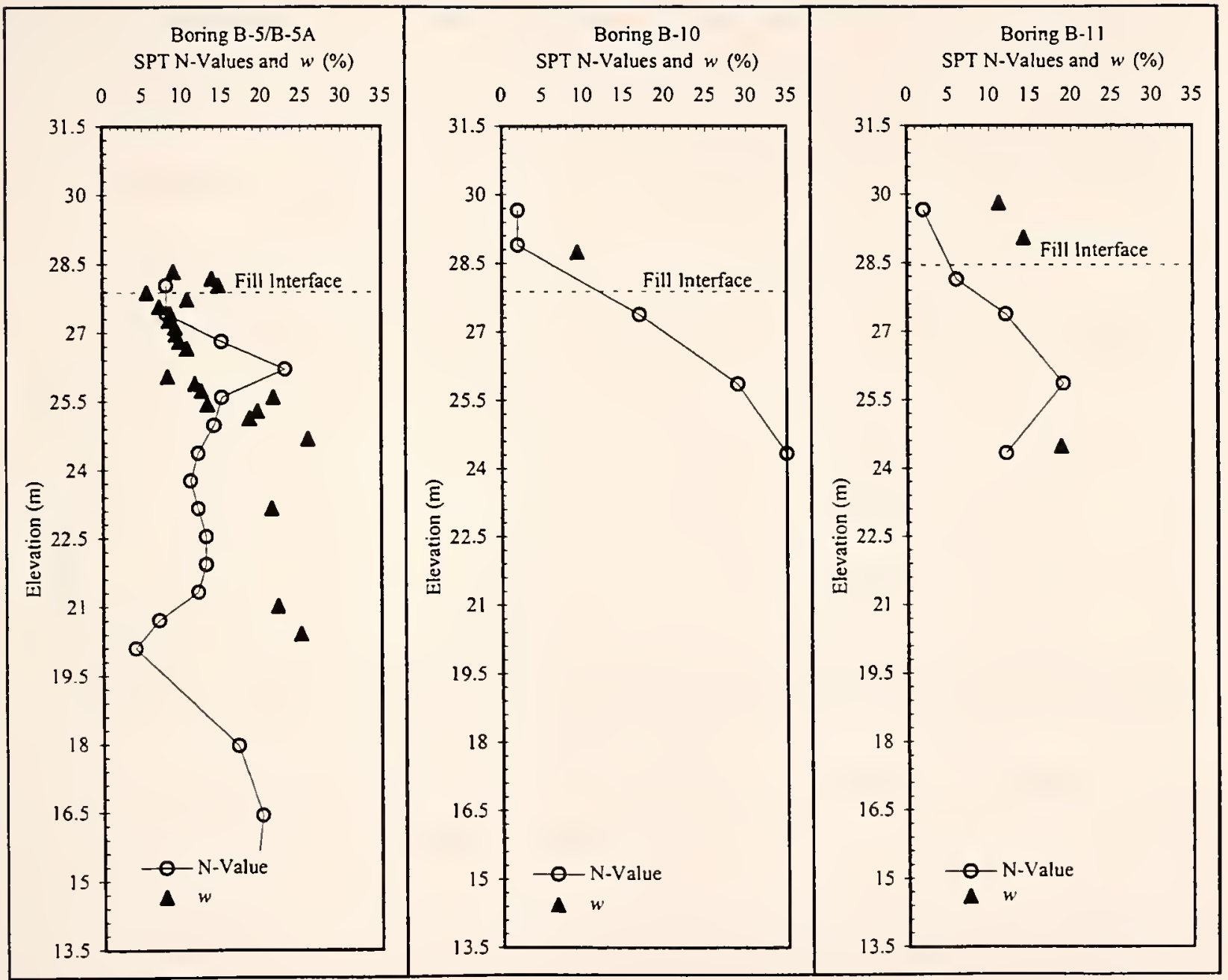

Figure 4.4 (con't.). Standard penetration test data and water content profiles, I-69, Madison County, Greenfield District. 
Two cone penetration tests (CPT) were performed at this project site by Purdue University. CPT data are presented in Figure 4.5 and Figure 4.6. The tests were performed adjacent to the shoulder of the highway, offset approximately 6 feet from the edge of pavement. CPTs were performed to evaluate the consistency of the embankment. $\mathrm{CPT}$ provides a continuous profile of sub-surface stratigraphy; therefore, it is a superb tool for identifying soft zones or other discontinuities in natural and man-made deposits. No apparent weak zones or discontinuities were identified at the locations of the CPTs.

Table 4.3. Laboratory strength test data, I-69, Madison Co., Greenfield District.

\begin{tabular}{llll}
\multicolumn{1}{c}{ Sample } & \multicolumn{1}{c}{ Depth $(\mathrm{m})$} & \multicolumn{1}{c}{$\phi^{\prime}\left(^{\circ}\right)$} & \multicolumn{1}{c}{$c^{\prime}(\mathrm{kPa})$} \\
\hline RB-1, ST-1 & $0.6-1.2$ & 34 & 0 \\
RB-1, ST-2 & $1.2-1.8$ & 30.2 & 10.8 \\
RB-2, ST-1 & $1.2-1.8$ & 32.8 & 0 \\
RB-1, BS-1 & Bag sample $^{(1)}$ & 36.6 & 0 \\
RB-2, BS-1 & Bag sample $^{(2)}$ & 38.6 & 0 \\
\hline
\end{tabular}

Notes: (1) Sample compacted to $\approx 97 \%$ of the maximum dry density determined by AASHTO T -99 and at $w \approx 11.7 \% . \rho_{\text {Dry, } \max .}=1921 \mathrm{~kg} / \mathrm{m}^{3}, O M C=12.3 \%$.

(2) Sample compacted to $\approx 97 \%$ of the maximum dry density determined by AASHTO T- 99 and at $w=11 \%$. $\rho_{\mathrm{Dry}, \max .}=2009 \mathrm{~kg} / \mathrm{m}^{3}, O M C=10.9 \%$.

Five standard Proctor tests were performed on soils collected from the failed embankment. Four of the samples, S-101 through S-104, were randomly collected. The fifth sample was a composite sample consisting of soils excavated from five sand-cone density tests. Summaries of the standard Proctor and the five sand-cone density tests are presented in Table 4.4 and Table 4.5, respectively.

As indicated in Table 4.4, the maximum dry density determined from standard Proctor tests ranged from 1,925 to $2,024 \mathrm{~kg} / \mathrm{m}^{3}$, and the optimum moisture content ranged from 10.5 to 13.3 percent. Sand-cone tests indicate that relative compaction of the fill used to widen the embankment ranged from approximately 79 to 90 percent. In addition, the moisture contents determined for the field density tests indicate that the soils ranged 


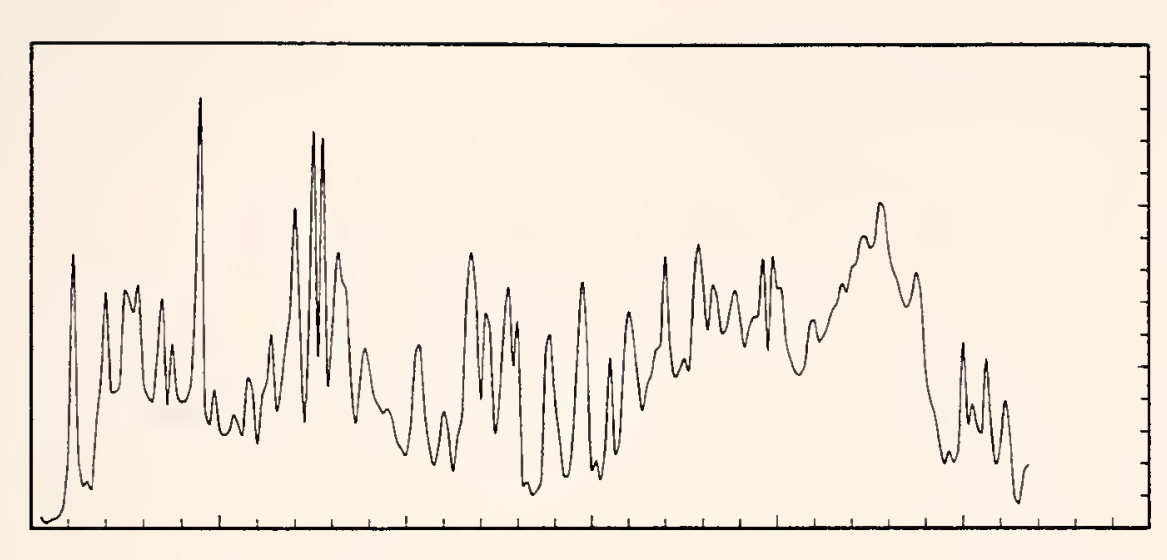

$\stackrel{0}{0}$
0
0

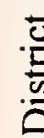

음

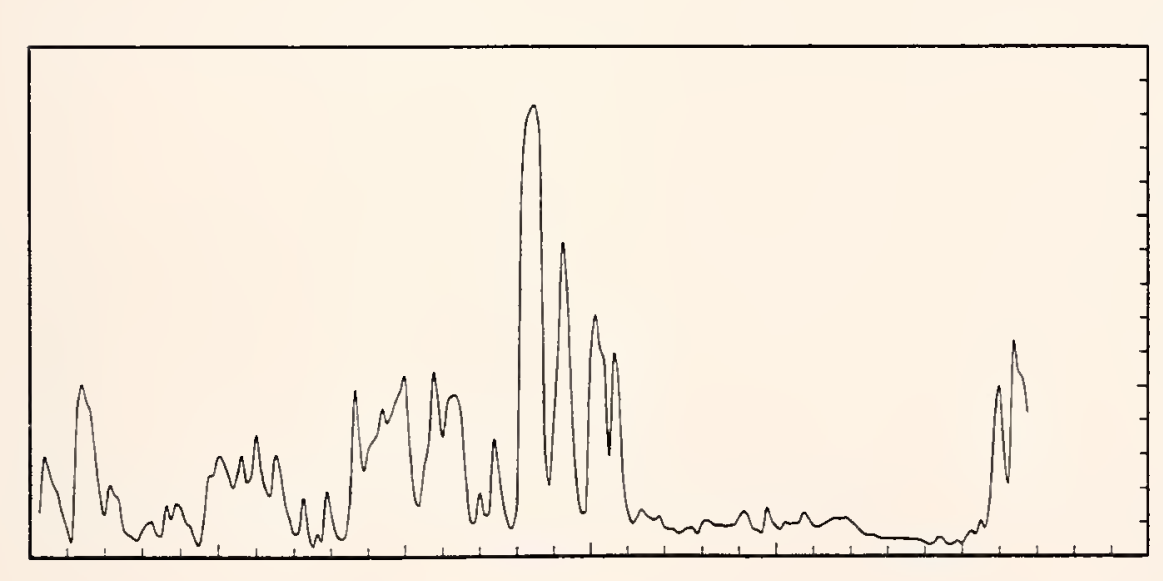

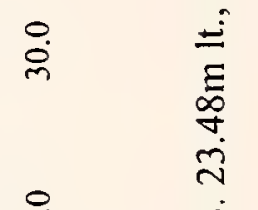

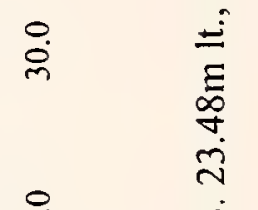

¿े.

$\begin{array}{cc}0 \\ \sum \\ 0 \\ 0 & 0 \\ 0 & 0 \\ 0 & 0\end{array}$

$\stackrel{0}{\circ}$

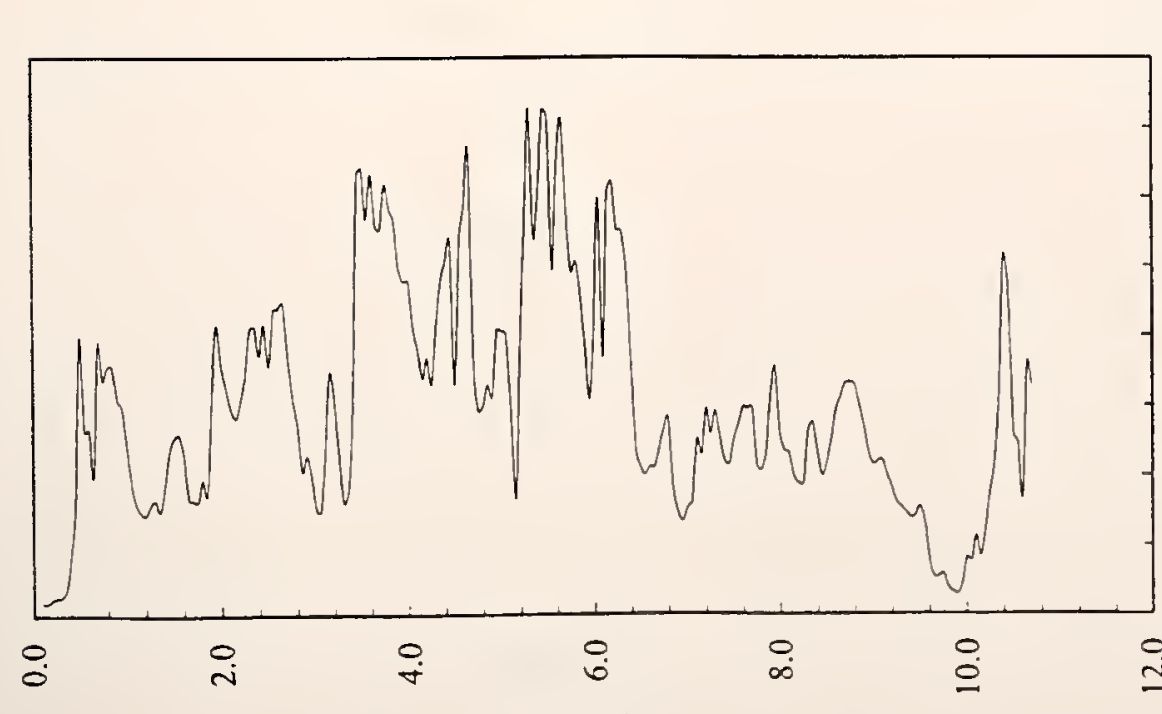

(u) पा dəa

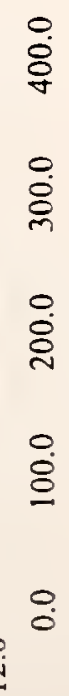

용

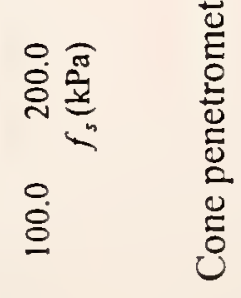

웅

官 


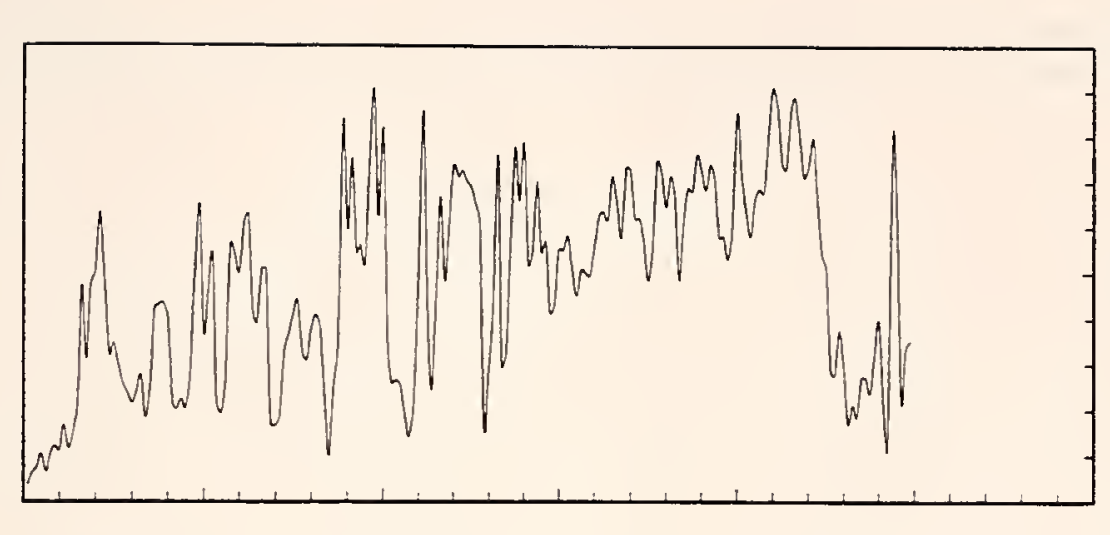

$\circ$
0

نั.

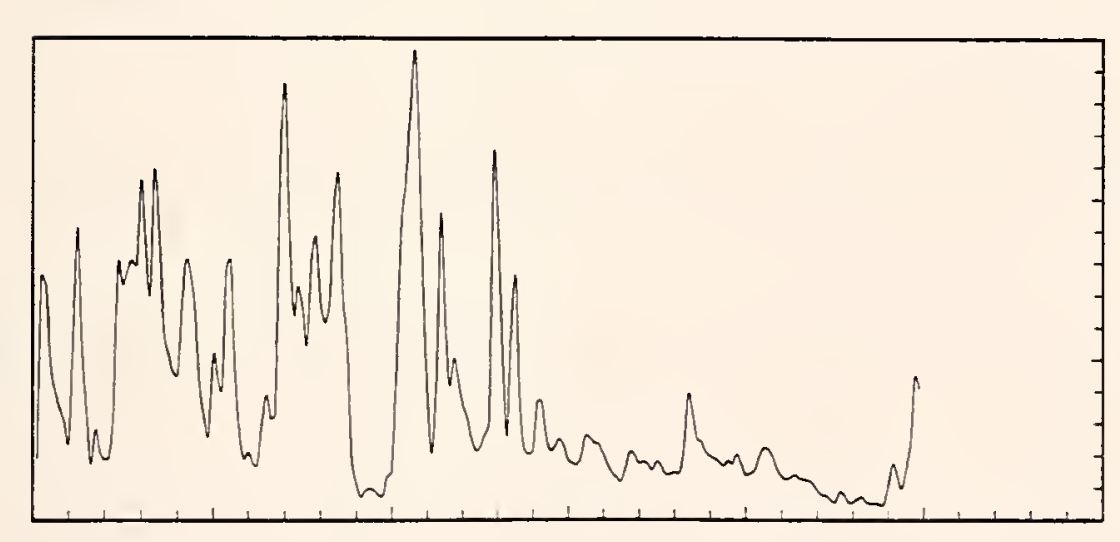

0
0
0
0

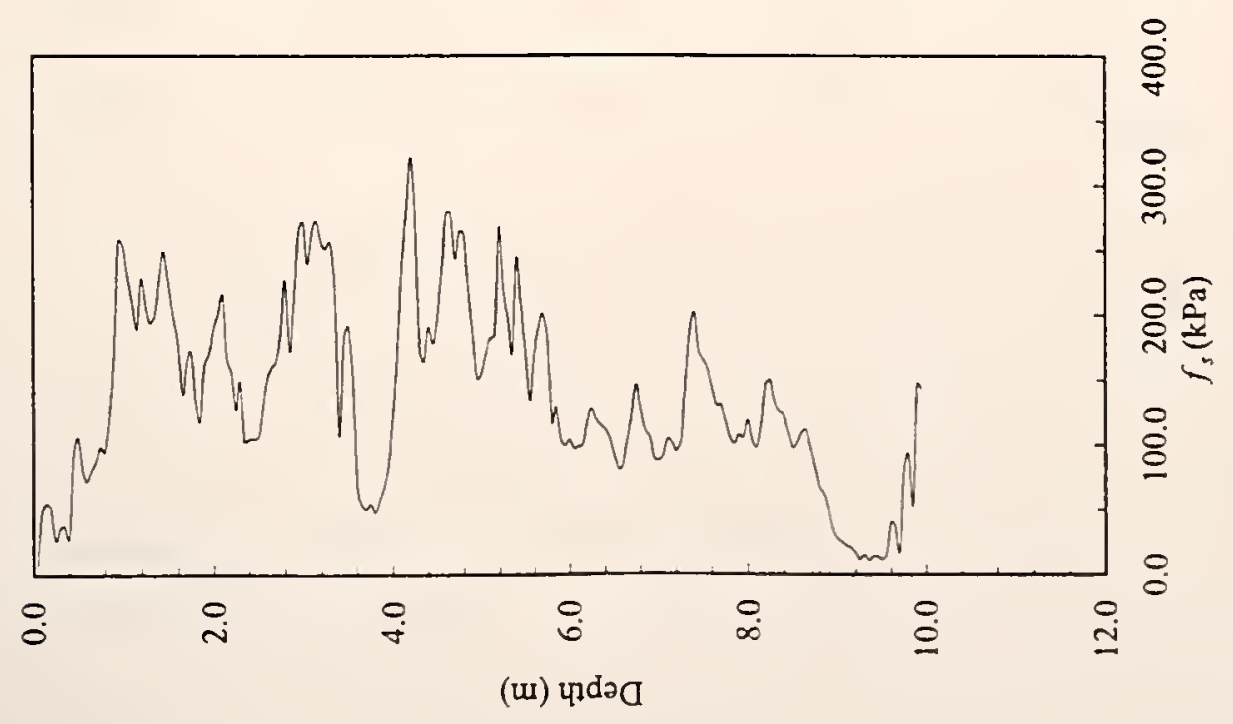

Final Report - September 1999 
from 3.7 to 8.7 percent wet of optimum. These data and the moisture density relationship are presented in Figure 4.7.

Table 4.4. Standard Proctor test data, I-69, Madison Co., Greenfield District

\begin{tabular}{|c|c|c|c|c|}
\hline Sample & $\begin{array}{l}\rho_{D r y, \max } \\
\left(\mathrm{kg} / \mathrm{m}^{3}\right)\end{array}$ & $O M C(\%)$ & $w_{l}(\%)$ & $I_{P}$ \\
\hline S-101 & 2012 & 10.9 & 29 & 14 \\
\hline S-102 & 1993 & 12.0 & 29 & 13 \\
\hline S-103 & 1935 & 13.2 & 30 & 14 \\
\hline S-104 & 1925 & 13.3 & 31 & 16 \\
\hline Composite & 2024 & 10.5 & - & - \\
\hline
\end{tabular}

Table 4.5. Sand-cone test data, I-69, Madison Co., Greenfield District

\begin{tabular}{rllllll}
\hline Test & $\begin{array}{c}\rho_{d r y, \text { in-situ }} \\
\left(\mathrm{kg} / \mathrm{m}^{3}\right)\end{array}$ & $R C(\%)$ & $w_{\text {in-situ }}(\%)$ & $w_{l}(\%)$ & $I_{p}$ \\
& \multicolumn{1}{c}{ (\%) } & & & & \\
\hline S-110 & 1608 & 79.45 & 15.2 & 27 & 12 & 15 \\
S-111 & 1824 & 90.12 & 14.2 & 29 & 12 & 13 \\
S-112 & 1600 & 79.05 & 14.6 & 26 & 16 \\
S-113 & 1778 & 87.85 & 15.9 & 28 & 30 & 16 \\
S-114 & 1597 & 78.90 & 19.2 & 30 & \\
\hline
\end{tabular}

Three additional sand-cone tests were performed in the fill. Two of these tests, S200 and S-201 were performed in original embankment soils, and the third test was performed in soils placed on the slope. The results of these tests are presented in Table 4.6. Although limited testing was performed on the soils comprising the original embankment, the data indicates that these soils exist at greater densities than those used to widen the embankment. 


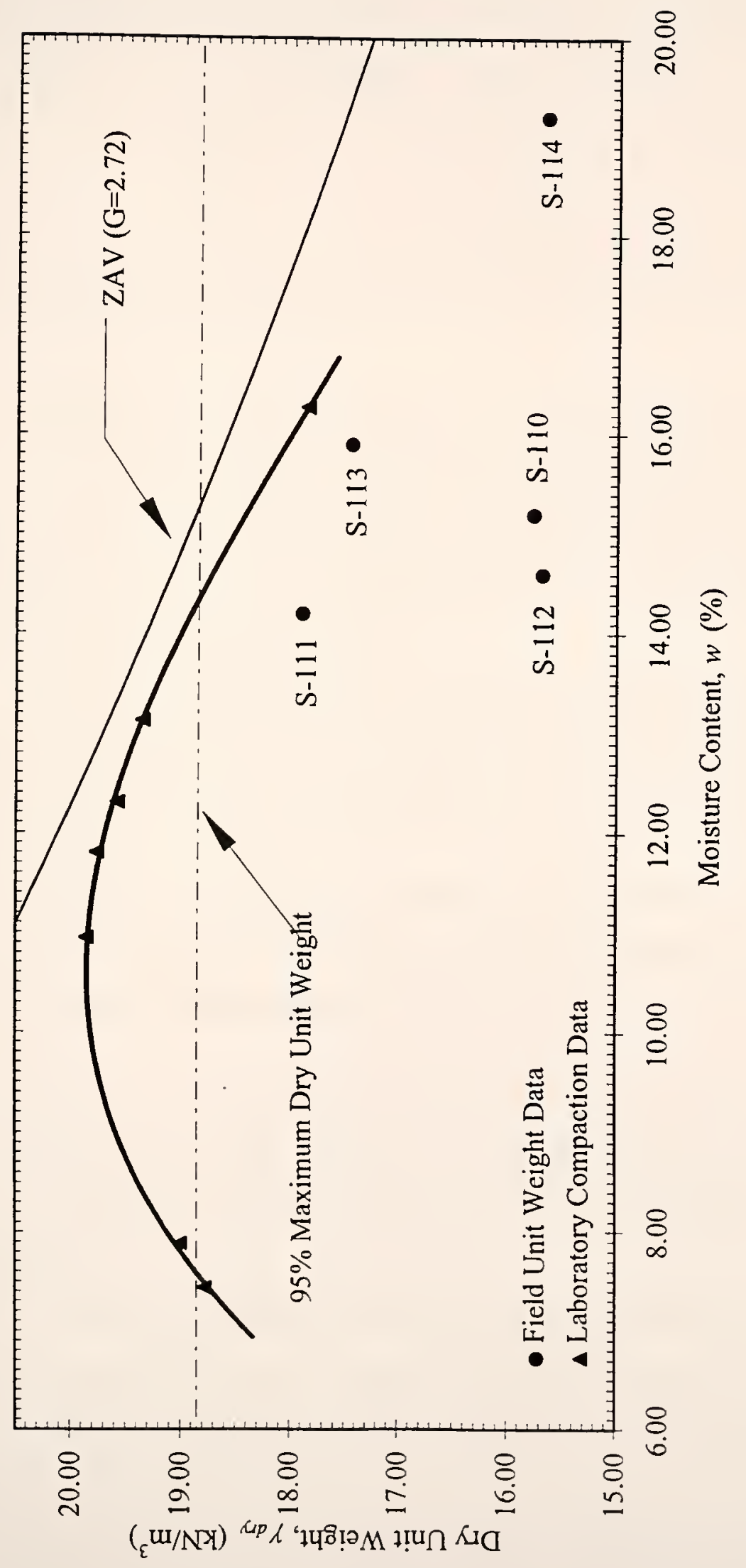

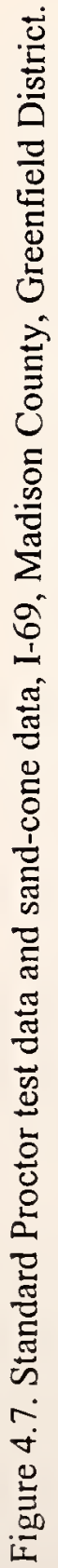


Table 4.6. Additional sand-cone test data, I-69, Madison Co., Greenfield District

\begin{tabular}{llll}
\hline Test & $\rho_{d r y, \text { in-situ }}\left(\mathrm{kg} / \mathrm{m}^{3}\right)$ & Range of $R C(\%)^{(1)}$ & $w_{\text {in-situ }}(\%)$ \\
\hline S-200 & 1826 & $90.2-94.9$ & 15.3 \\
S-201 & 1846 & $91.2-95.9$ & 14.9 \\
S-202 & 1794 & $88.6-93.2$ & 11.8 \\
\hline
\end{tabular}

Notes: (1) Based on range of maximum dry densities determined from standard Proctor tests as presented in Table 4.4.

Vertical and horizontal deformation was measured by INDOT and is presented in Figures 4.8 and 4.9 , respectively. Review of vertical deformation data reveals that the greatest settlement occurred in the sideslope, near the shoulder of the road and decreased with increasing distance from the centerline of I-69. No vertical displacement was noted at the toe of the embankment or beyond.

Horizontal deformation data covers a relatively short time period. Aside from an anomalous reading at Sta. $452+00$, no significant horizontal deformation was noted at the toe of the slope. Horizontal displacement at the crest was less than $300 \mathrm{~mm}$ for the time period considered.

The data indicate that vertical and horizontal deformations were greatest near the shoulder of the road, and were confined to the slope. The maximum fill depth was at the shoulder of the road. No deep-seated movement was noted at or near the toe of the structure.

One test pit was excavated in the sideslope of the embankment, and the removal of soils comprising the wedge of fill placed on the sideslope was observed to visually identify potential discontinuities in the fill. The following is a summary of pertinent observations:

- The original embankment soils had clearly defined horizontal lifts, accentuated by color variations. No such layering was noted in the fill placed above the original embankment; this fill had a jumbled appearance. 
Station $452+00$

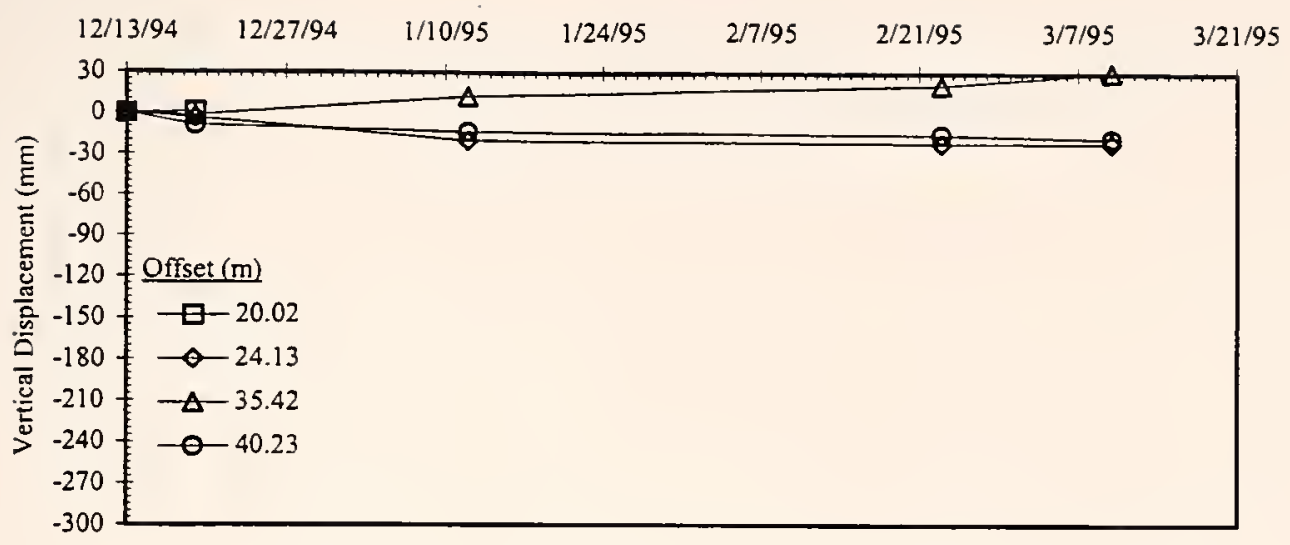

Station $453+00$

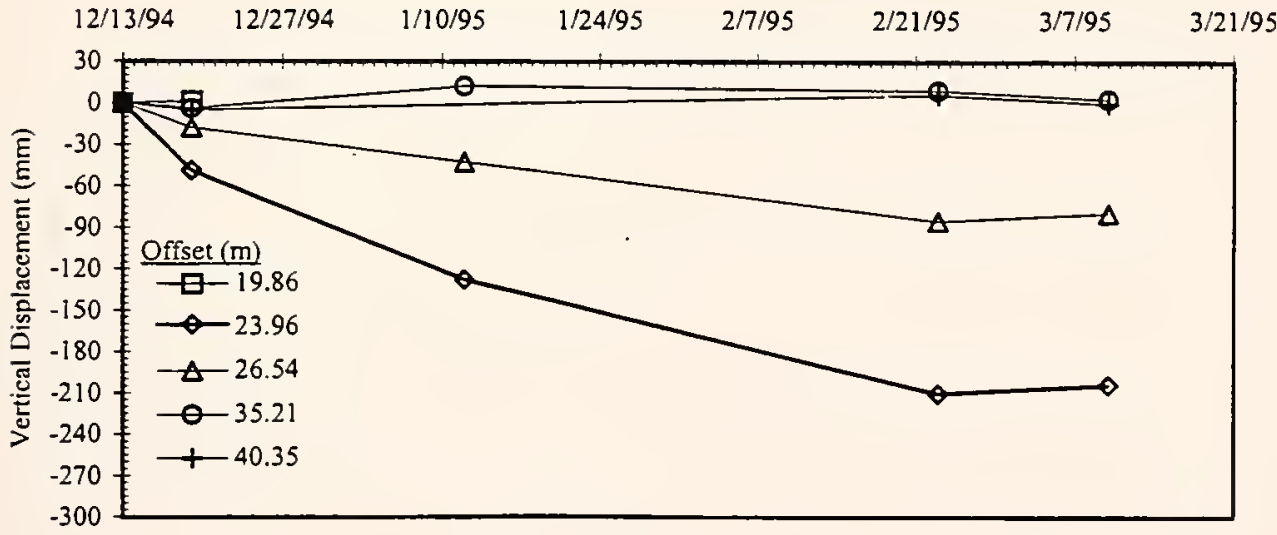

Station $454+00$

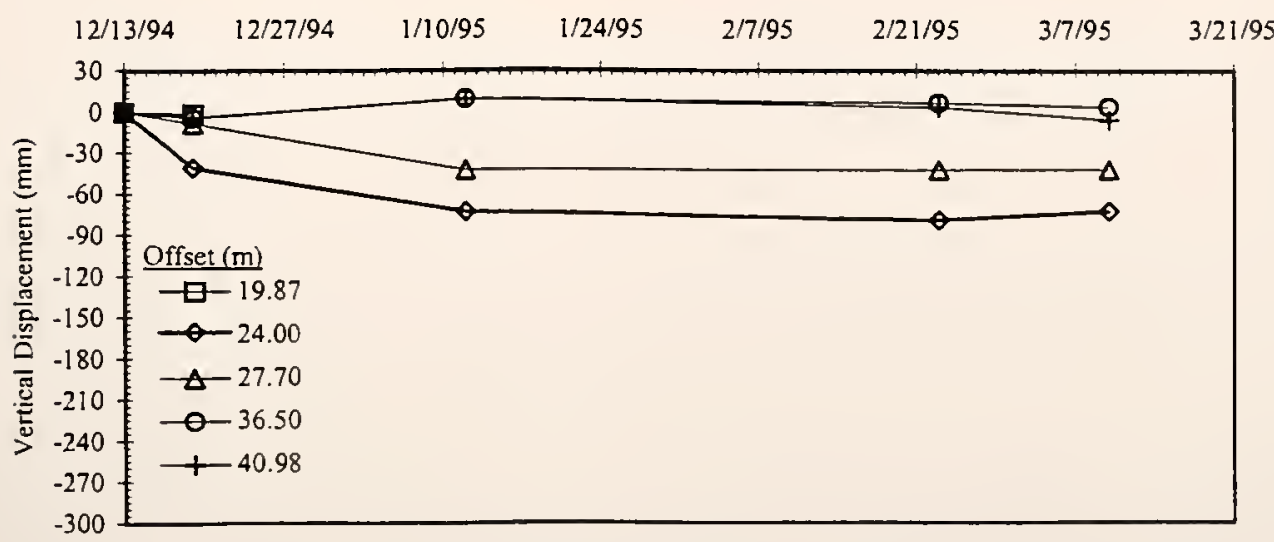

Figure 4.8. Vertical deformation data, I-69, Madison County, Greenfield District. 


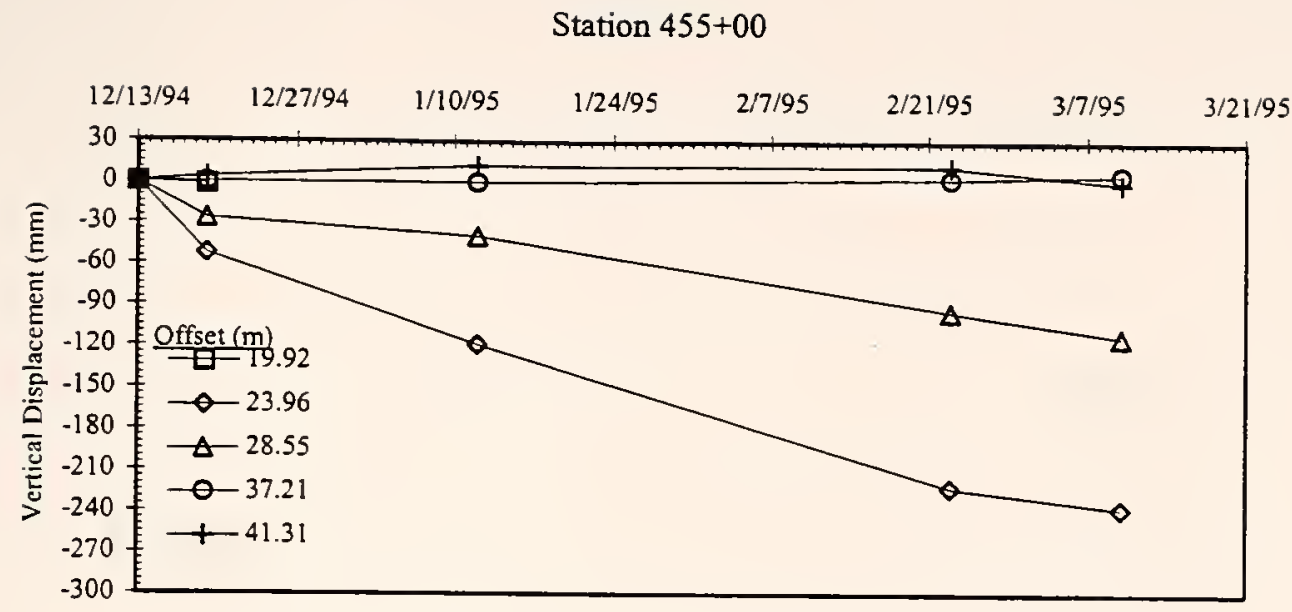

Station $456+00$

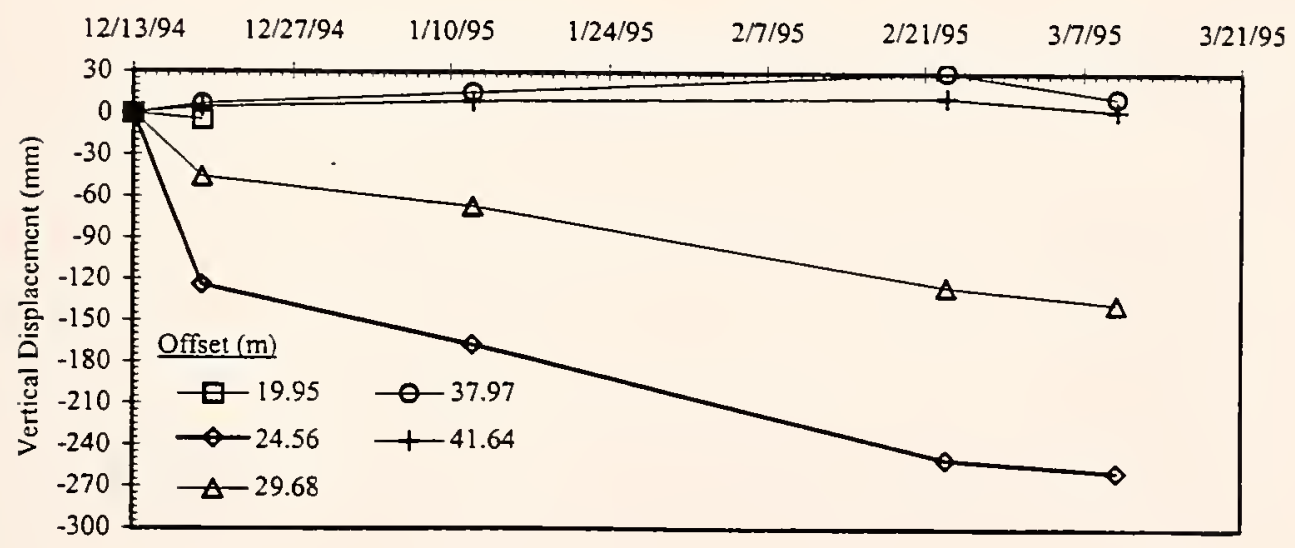

Station $457+00$

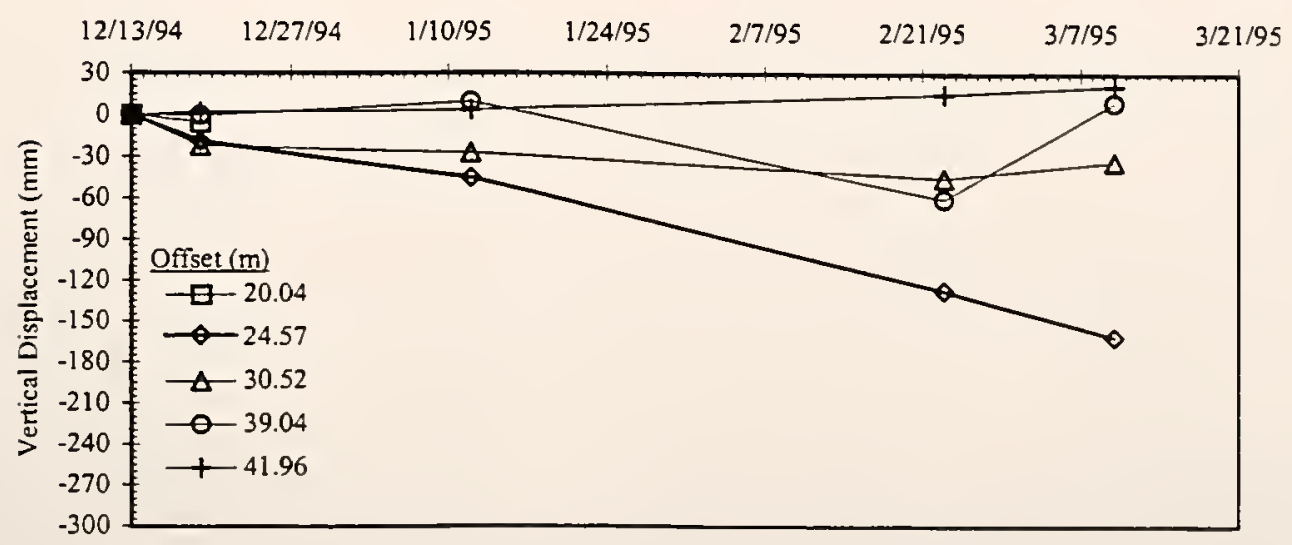

Figure 4.8 (con't.). Vertical deformation data, I-69, Madison County, Greenfield District. 
Station $452+00$

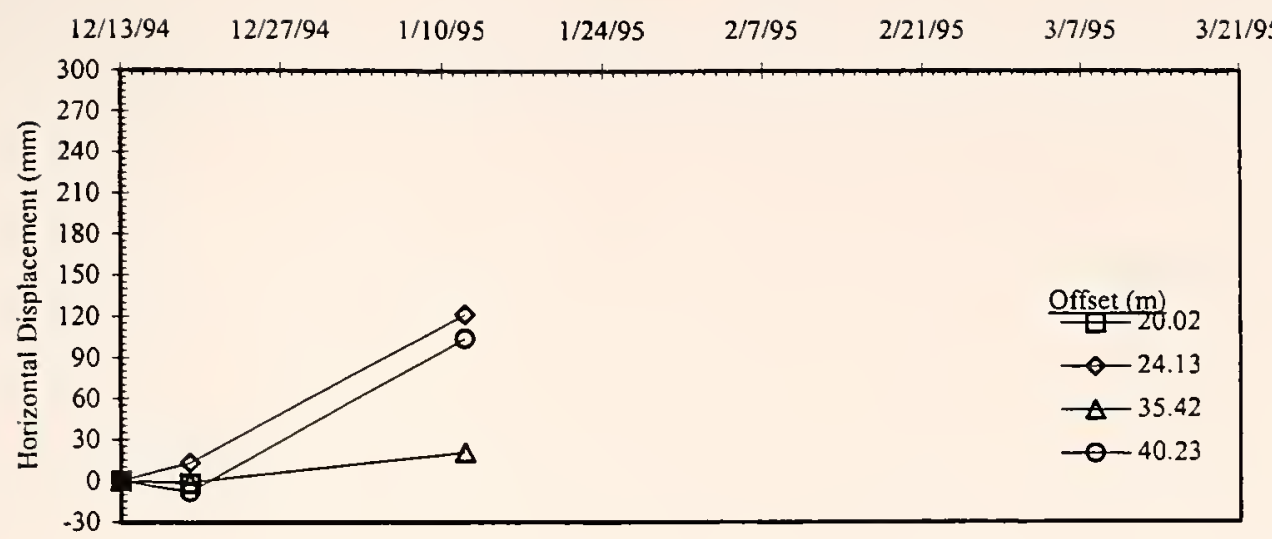

Station $453+00$

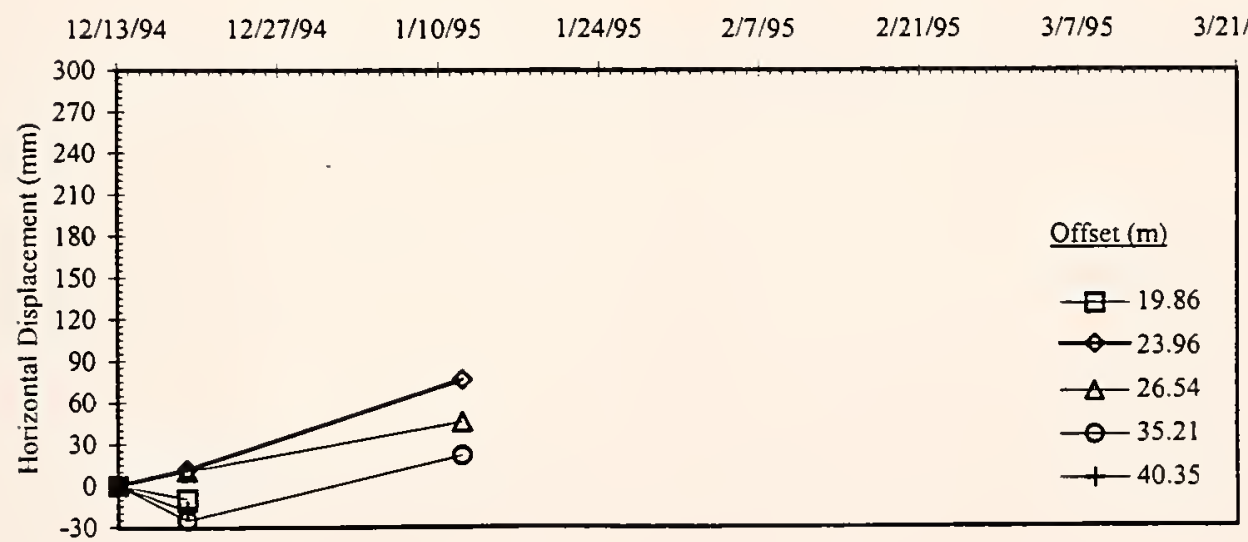

Station $454+00$

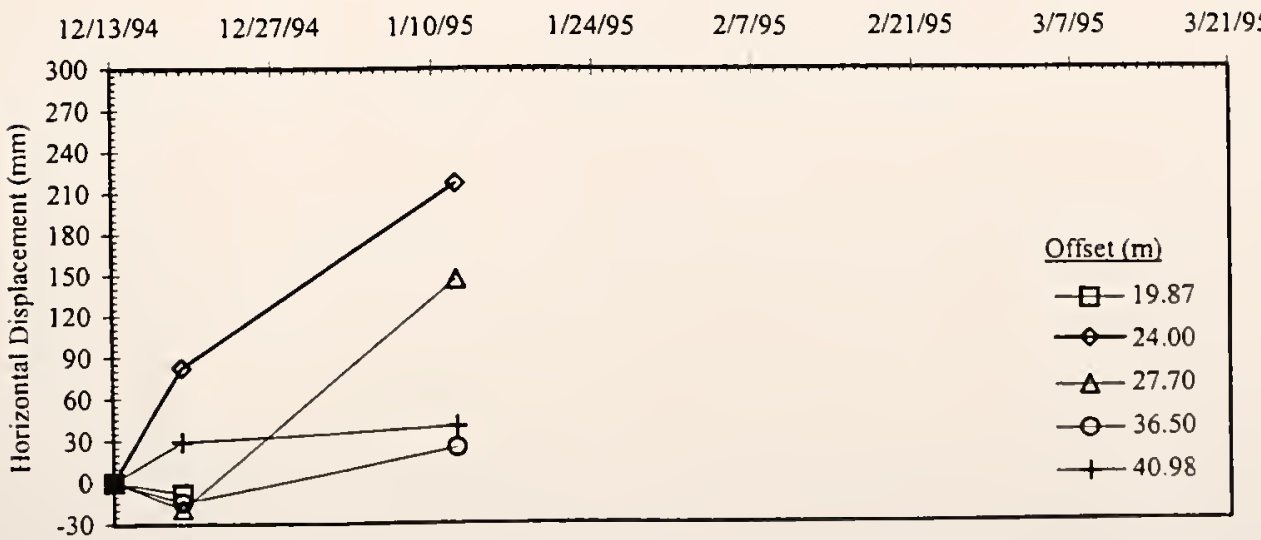

Figure 4.9. Horizontal deformation data, I-69, Madison County, Greenfield District. 
Station $455+00$

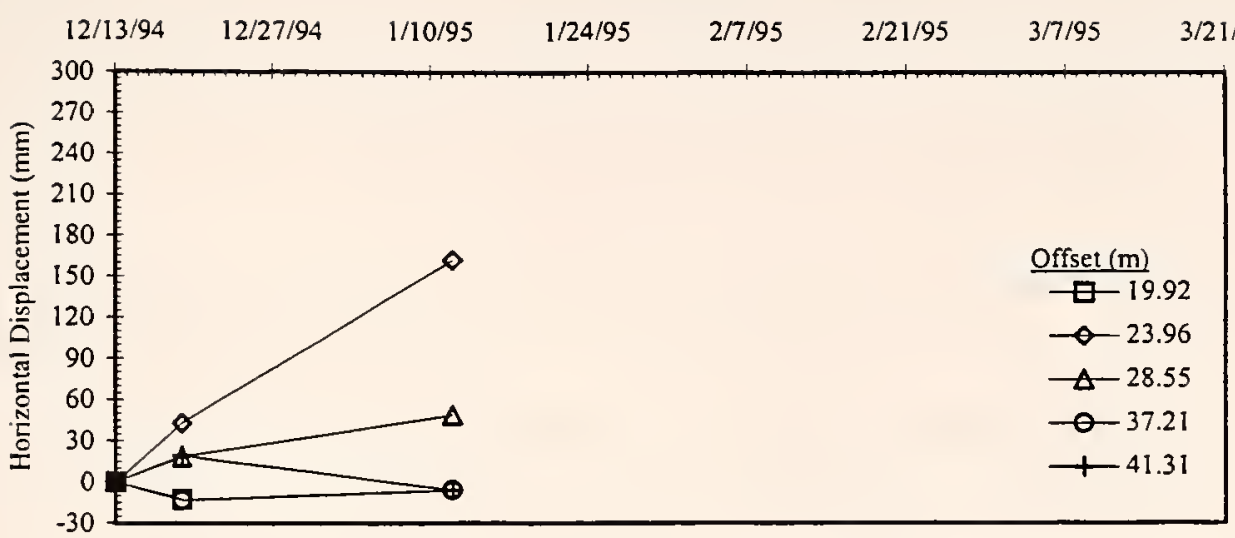

Station $456+00$

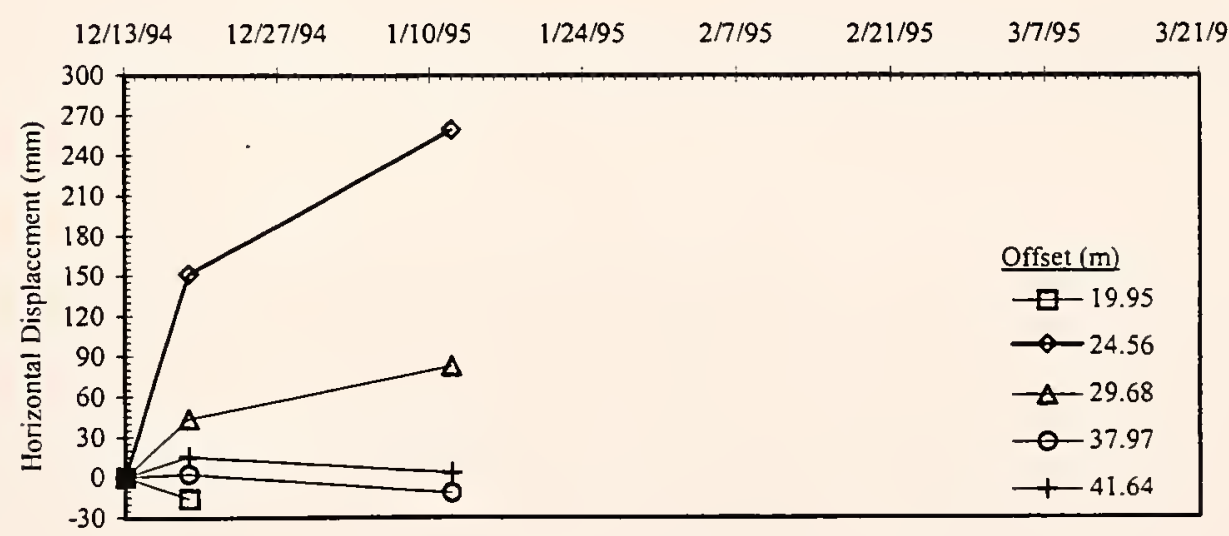

Station $457+00$

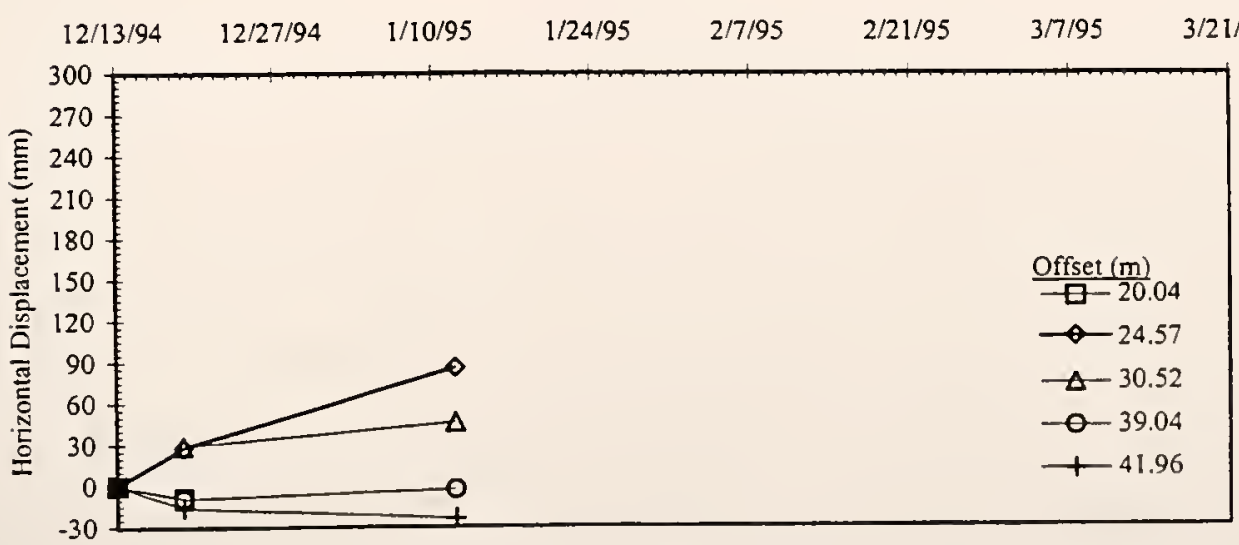

Figure 4.9 (con't.). Horizontal deformation data, I-69, Madison County, Greenfield District. 
- The interface between the original embankment and the fill placed to steepen the sideslope was typically identified by the presence of topsoil and roots. It could be visually observed that the fill placed on the sideslope was not well compacted. Soft, wet zones and cracks in the fill were visible.

Construction personnel involved in the original slope steepening project were candid, and indicated:

- Fill was end-dumped into place. A bulldozer dressed the slope, and no compaction equipment was used for soil placed on the sideslope.

- Fill primarily consisted of undercut. These poor quality soils were excavated during roadway reconstruction.

- Two benches were constructed at $1 / 3$ points along the slope; however, the benches were not wide and more closely resembled notches in the existing slope.

\subsubsection{I-69, Grant Co., Fort Wayne District (R-19972)}

Contract No. R-19972 involved reconstruction of I-69 between SR 26 and SR 22 in Grant County, Indiana. Work under this contract included steepening of an existing embankment sideslope to widen I-69. The west flank of the embankment was widened from south of the bridge carrying I-69 over Conrail Railway to south of the southbound entrance ramp at Exit 59. The extent of the widening project and the site location is presented in Figure 4.10:

The embankment widening was performed to increase the length of the southbound entrance acceleration lane. No additional right-of-way was required for the widening, and the toe of the slope apparently remained unchanged. The documentation that was reviewed indicates that finished grades after widening were on the order of $1.6 \mathrm{H}: 1 \mathrm{~V}$ to $1.4 \mathrm{H}: 1 \mathrm{~V}$. Following highway reconstruction sloughing of the slope occurred, and a scarp, approximately $70 \mathrm{~m}$ long, developed. The head of the scarp was offset $1.2 \mathrm{~m}$ to $1.8 \mathrm{~m}$ from the guardrail. Significant erosion of the sideslope in this area was noted during a site visit in January 1997. No pavement distress, however, was noted at this time or during site visits in July 1997. 


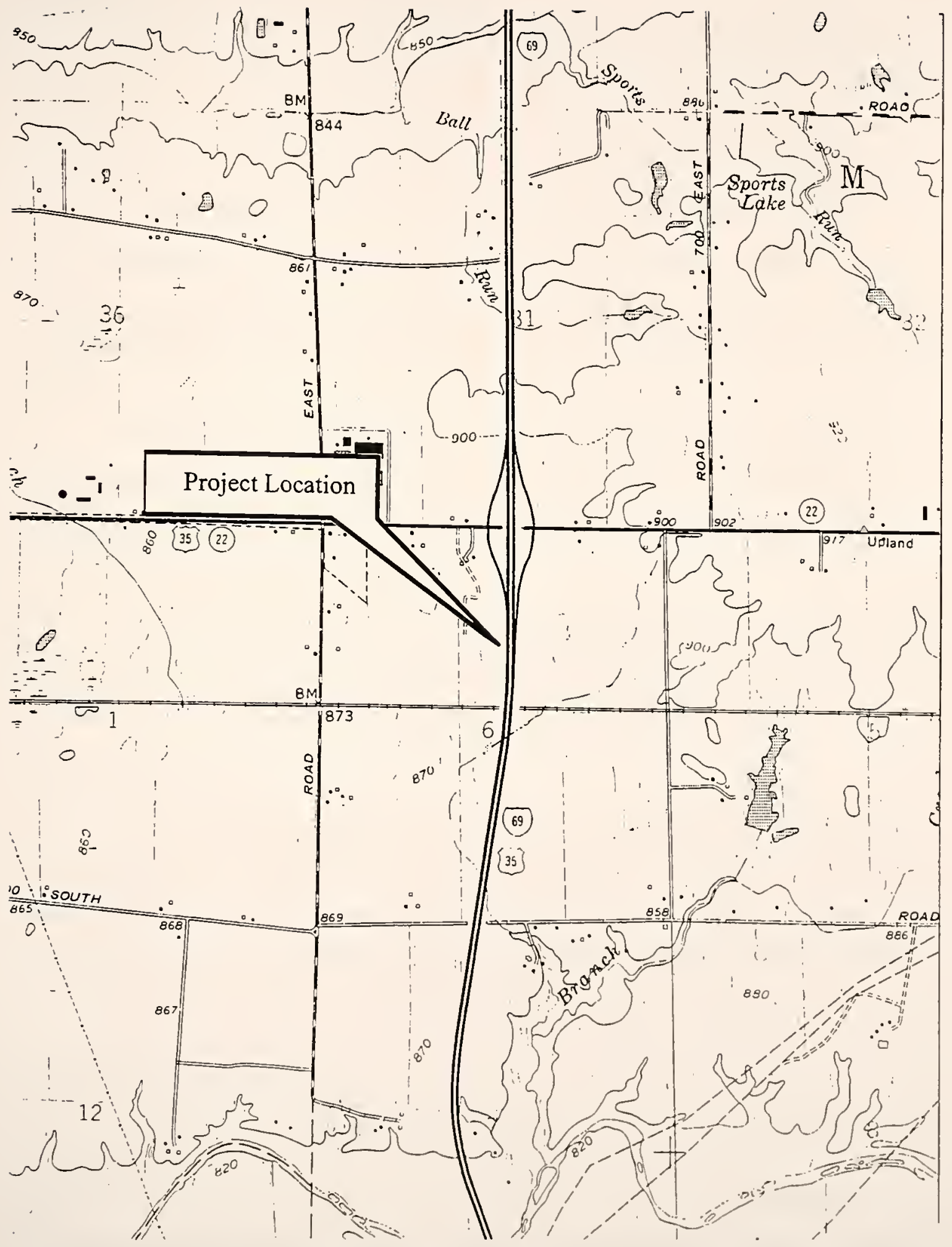

Figure 4.10. Site location map, I-69, Grant County, Fort Wayne District (Gas City Quadrangle, Indiana) 
Embankment Design and Construction Plans

No documents were obtained which indicated that the slopes were analyzed for stability; however, INDOT (1991) did provide general recommendations for slope design for this project. These recommendations were prepared as a response to a letter sent to INDOT by CEA (1991), the projects design consultant. The recommendations were based on limited subsurface information and soil maps for the area, and included benching, compaction and proofrolling in accordance with INDOT Standard Specifications. In addition, INDOT, knowledgeable that slopes as steep as $1.5 \mathrm{H}: 1 \mathrm{~V}$ were being considered, recommended encasing slopes steeper than $2 \mathrm{H}: 1 \mathrm{~V}$ with rip-rap or rock backfill.

Construction plans were reviewed. Construction plans did not incorporate INDOT's design recommendations. Cross-sections of the embankment depicting the existing sideslope geometry, required benching, and the final sideslope geometry after widening were not included in the plans.

As part of this project the curb and all drainage structures on the shoulder of I-69 were removed where embankment widening was performed. Surface water, previously managed in a controlled manner, was now directed to the sideslopes.

\section{Construction Records}

As-built plans for the project were reviewed. Cross-sections documenting construction of the sideslopes were not prepared as part of the as-built drawings. The final sideslope geometry was not noted on the as-built plans. No field compaction test data for fill placed on the sideslope could be located. In essence, no pertinent records documenting the construction of the embankment were located for review.

Post-Failure Investigation Data

Four borings were advanced by INDOT subsequent to failure. SPT and moisture content profiles are presented in Figure 4.11. RB-1, RB-3 and RB-4 were advanced through the embankment. RB-2 was advanced at the toe of the embankment. The maximum estimated depth of the fill $(\approx 1.83 \mathrm{~m})$ based on sideslope geometry is presented on the profiles; however, observations made in test pits indicate that the depth to original 

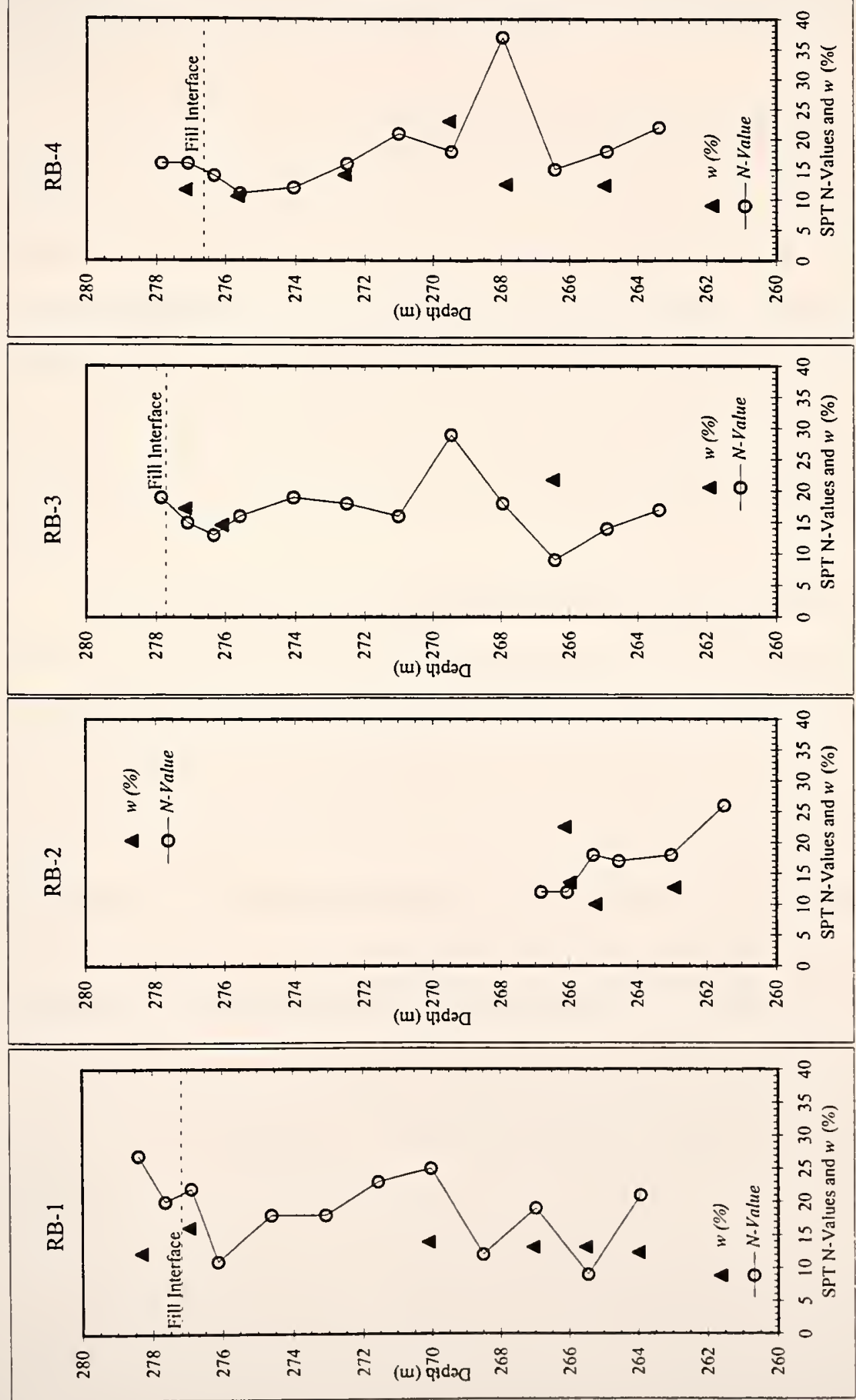

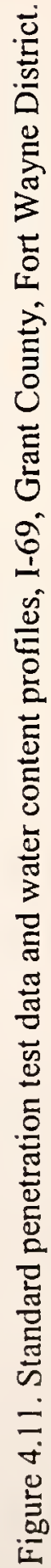


ground was shallower. The borings indicate that the consistency of the soil comprising the embankment and foundation is stiff to very stiff. No weak zones indicative of a rupture zone were noted.

Four shallow test pits, approximately $1.5 \mathrm{~m}$ deep, were excavated in the sideslope during reconstruction of the embankment (Contract No. R-22739). Samples were collected from the test pits. Index test data are summarized in Table 4.7. As indicated in Table 4.7, the embankment is comprised of granular and cohesive soils. The granular soils recovered from the test pit were surficial soils located above a weathered layer containing roots. This weathered layer, typically within a few feet of the existing grade, was interpreted as the original embankment. The surficial granular soils were loose and tended to ravel into the test pits. The original embankment soils were medium stiff when first encountered and become stiff to very stiff within a few feet of the weathered topsoil layer.

Six in-situ density tests were performed at the site, and the results are presented in Table 4.8. Four of these tests were in the near surface soils of the original embankment, identified by weathering and the presence of roots. Two tests were performed in the granular soils placed during embankment widening; additional tests were not performed as these soils tended to be granular and loose. In the granular soils (Sta. 19+440 and $19+470$ ) relative compaction ranged from 83.9 to 91 percent. The low densities may be attributable to post-construction disturbance (e.g., sloughing and erosion); however, no construction records were available which would indicate these soils were placed in accordance with INDOT Standard Specifications during embankment widening. The lower densities in the upper portion of the original embankment soils (Sta. 19+450, Sta. $19+429$, Sta. $19+423$, Sta. $19+480$ ) are attributed to weathering. Had benching been performed, these weathered soils would have been removed, and the root layer would not be present. 
Table 4.7. Index test data, I-69, Grant County, Fort Wayne District.

\begin{tabular}{|c|c|c|c|c|c|c|c|}
\hline Sample & $\begin{array}{c}w_{\text {in-situ }} \\
(\%)\end{array}$ & $w_{l}(\%)$ & $I_{p}$ & No. 4 & No. 10 & No. 40 & No. 200 \\
\hline $\begin{array}{l}\text { Sta. } 19+440 \\
\text { O.S. } 1.52 \mathrm{~m} \text { EOP }\end{array}$ & 9.4 & NP & - & 60.4 & 42.8 & 19.9 & 8.9 \\
\hline $\begin{array}{l}\text { Sta. } 19+450 \\
\text { O.S. } 4.88 \mathrm{~m} \text { EOP }\end{array}$ & 11.9 & 25.5 & 11 & - & - & - & - \\
\hline $\begin{array}{l}\text { Sta. } 19+470 \\
\text { O.S. } 1.68 \mathrm{~m} \text { EOP }\end{array}$ & 5.4 & NP & - & 66.0 & 48.5 & 22.2 & 10.1 \\
\hline $\begin{array}{l}\text { Sta. } 19+423 \\
\text { O.S. } 3.05 \text { EOP }\end{array}$ & 17.5 & 29.3 & 14 & 98.1 & 95.9 & 89.6 & 69.2 \\
\hline $\begin{array}{l}\text { Sta. } 19+480 \\
\text { O.S. } 1.83 \mathrm{~m} \text { EOP }\end{array}$ & - & NP & - & 70.21 & 57.4 & 23.9 & 8.3 \\
\hline Interface, BS-8 & 25.0 & 23.2 & 10 & - & - & - & - \\
\hline TP No. 1, BS-1 & 6.3 & NP & - & 71.7 & 54.6 & 21.3 & 12.0 \\
\hline TP No. 2, BS-7 & 6.8 & NP & - & 72.9 & 52.8 & 25.8 & 11.2 \\
\hline
\end{tabular}

Inspection of the test pits did not reveal a rupture zone or discontinuity in the fill; however, it did appear as though sliding may have occurred at the interface between the original embankment and the fill placed on the sideslope. While constructing a bench during the repair work, fill slid off the sideslope, revealing a soft layer of soil approximately $15 \mathrm{~m}$ long and $3 \mathrm{~m}$ wide. The slide surface was located at mid-slope, and was parallel to the plane of the slope. The depth from existing grade to this layer ranged from 0.3 to $0.6 \mathrm{~m}$. Index tests on this sample (Interface BS-8) indicated a liquid limit of $23.2 \%$ while the natural water content was $25 \%$. Visually this layer of soil had a viscous appearance, and ranged from $25 \mathrm{~mm}$ to $100 \mathrm{~mm}$ in thickness. Roots were noted in this layer. 
Table 4.8. Sand-cone and standard Proctor test data, I-69, Grant County, Fort Wayne District

\begin{tabular}{|c|c|c|c|c|c|}
\hline Sample & $\begin{array}{c}\rho_{d r y, \text { in-situ }} \\
\left(\mathrm{kg} / \mathrm{m}^{3}\right)\end{array}$ & $w_{\text {in-situ }}(\%)$ & $\begin{array}{l}\rho_{d r y, \max } \\
\left(\mathrm{kg} / \mathrm{m}^{3}\right)\end{array}$ & $O M C(\%)$ & $R C(\%)$ \\
\hline Sta. $19+440$ & 1829 & 9.4 & $2180^{(1)}$ & 8.1 & 83.9 \\
\hline \multicolumn{6}{|l|}{ O.S. $1.52 \mathrm{~m}$ EOP } \\
\hline Sta. $19+450$ & 1735 & 11.9 & $1950^{(2)}$ & 12.6 & 89.0 \\
\hline \multicolumn{6}{|l|}{ O.S. $4.88 \mathrm{~m}$ EOP } \\
\hline Sta. $19+470$ & 1986 & 5.4 & $2183^{(1)}$ & 8.0 & 91.0 \\
\hline \multicolumn{6}{|l|}{ O.S. $1.68 \mathrm{~m}$ EOP } \\
\hline Sta. $19+429$ & 1806 & 14.8 & - & - & - \\
\hline \multicolumn{6}{|l|}{ O.S. $3.05 \mathrm{~m}$ EOP } \\
\hline Sta. $19+423$ & 1612 & 17.5 & $1845^{(2)}$ & 15.6 & 87.4 \\
\hline \multicolumn{6}{|l|}{ O.S. $3.05 \mathrm{EOP}$} \\
\hline Sta. $19+480$ & 1576 & 19.6 & - & - & - \\
\hline O.S. 6.86 EOP & & & & & \\
\hline
\end{tabular}

Notes: (1) AASHTO T-99 (Method C), oversize replaced.

(2) AASHTO T-99 (Method A).

A second discontinuity was noted at the shoulder of the road. Desiccated, surficial soils were removed revealing a remnant topsoil layer. The presence of these layers confirms that benching was not performed.

Although cohesive soils were present in the surficial fill, in the area where the most severe distress was noted, the surficial soils were primarily coarse grained. The surficial fill had a jumbled appearance and the soils were not knit together, suggesting that compaction, if used, was not adequate. These coarse grained soils are highly erodible as confirmed by the presence of erosion channels across the slope.

The operator excavating the embankment for reconstruction also indicated that the soils in the area where severe distress was noted tended to be granular, 
loose, and easily excavated to a depth of $0.6 \mathrm{~m}$ to $1 \mathrm{~m}$. Soils outside of this area tended to be more cohesive and stiffer.

A discussion with INDOT personnel familiar with the original embankment widening confirmed that no benching was performed. In addition, this representative indicated that fill was not carried to the toe of the slope, and that the depth of the fill was minor, perhaps $1 \mathrm{~m}$ at the shoulder of the road.

\subsubsection{Calumet Avenue Interchange, Lake Co., LaPorte District (R-19181)}

Work performed under Contract No. B-19181 comprised reconstruction of the

Calumet Avenue Interchange of I-80/I-94 east and west of the Calumet Avenue Interchange. The site location is presented in Figure 4.12. As part of this project the embankment was widened. Failure reportedly occurred on the south side of the I-80/-94 between Hohman Avenue (Sta. 102+50, Line KK) overpass and the Harrison Avenue overpass (Sta. 117+69, Line KK). Distress of the embankment comprised sloughing at the slope crest according to LaPorte District personnel.

\section{Embankment Design and Construction Plans}

Design documents were not available for the sideslope steepening project suggesting that stability of the steepened embankment was not analyzed. Cross-sections for the proposed widening and steepening were provided in the plans. Plans indicate that between these bridges the embankment, approximately $8.5 \mathrm{~m}$ high, was widened up to $5.5 \mathrm{~m}$. The existing and proposed sideslope geometries were indicated on the Construction Plans. The inclination of embankment sideslopes prior to widening was $2 \mathrm{H}: 1 \mathrm{~V}$, or shallower. After embankment widening, the inclination of the sideslopes as indicated on the plans was $2 \mathrm{H}: 1 \mathrm{~V}$. The required benching was presented on the plans, and benches were typically $3 \mathrm{~m}$ wide. The maximum thickness of the fill placed for embankment widening was approximately $2.4 \mathrm{~m}$.

\section{Construction Records}

As-built plans were reviewed and no changes to the initially proposed steepened slope geometry were noted. Over 800 in-situ density measurements on compacted soils were performed for this project. Twenty-three tests were performed in the east 


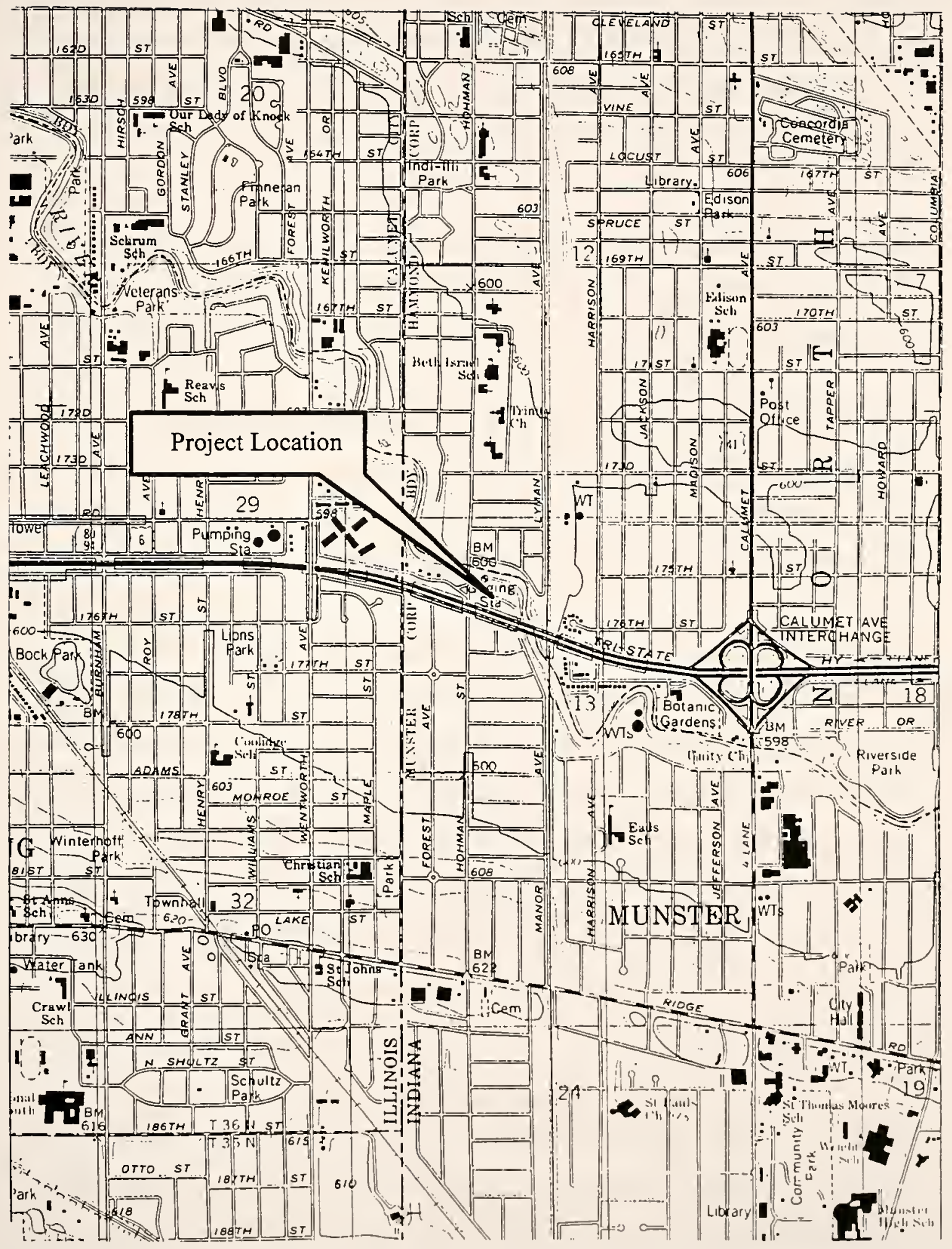

Figure 4.12 Site location map, Calumet Avenue Interchange, Lake Co., LaPorte District (Calumet City Quadrangle, Illinois-Indiana) 
embankment where distress was noted; however, twenty-two of these tests appear to have been performed on the cut bench after proofrolling. Only one test appears to have been performed on fill placed in the sideslope. The data indicates that benching and proofrolling was performed in accordance with INDOT Standard Specifications (1993).

\section{Site Visit}

Surface water is directed to the sideslope and no provisions for controlled surface water management exist (e.g., curbing, catch basins). This slope is not maintained (i.e., mowed) and a thick vegetative cover exists. No pavement distress was apparent. No significant slope distress was noted.

Construction of sound barrier wall foundations at the crest of the slope has been completed over the winter and spring of 1997. Excavation spoils have been left on the slope, and No. 2 stone has been placed at the crest. The presence of the excavation spoils and the No. 2 stone tends to direct surface water along the shoulder of the road, away from the slope.

As no significant distress was noted, LaPorte District personnel were contacted regarding the slope. They indicated that the failure occurred approximately five years ago during the winter following construction (i.e., 1991/1992). After the initial sloughing occurred, no additional movement was noted. The slough was relatively shallow, less than $0.6 \mathrm{~m}$ deep at the head. The distress was likely masked by the construction. An alternative site that illustrated a more severe degree of failure was sought, but none could be identified by INDOT personnel.

\subsection{Successful Sites}

\subsubsection{Wallen Road, Allen Co., Fort Wayne District (B-21135)}

Work performed under Contract No. B-21135 comprised the construction of a replacement structure over I-69. This structure carries Wallen Road, a two lane road, over I-69. The site location is presented in Figure 4.13. The existing embankment was widened and the road profile was redesigned, resulting in a maximum increase in elevation of approximately $0.6 \mathrm{~m}$. Plans indicate that the embankment was widened 


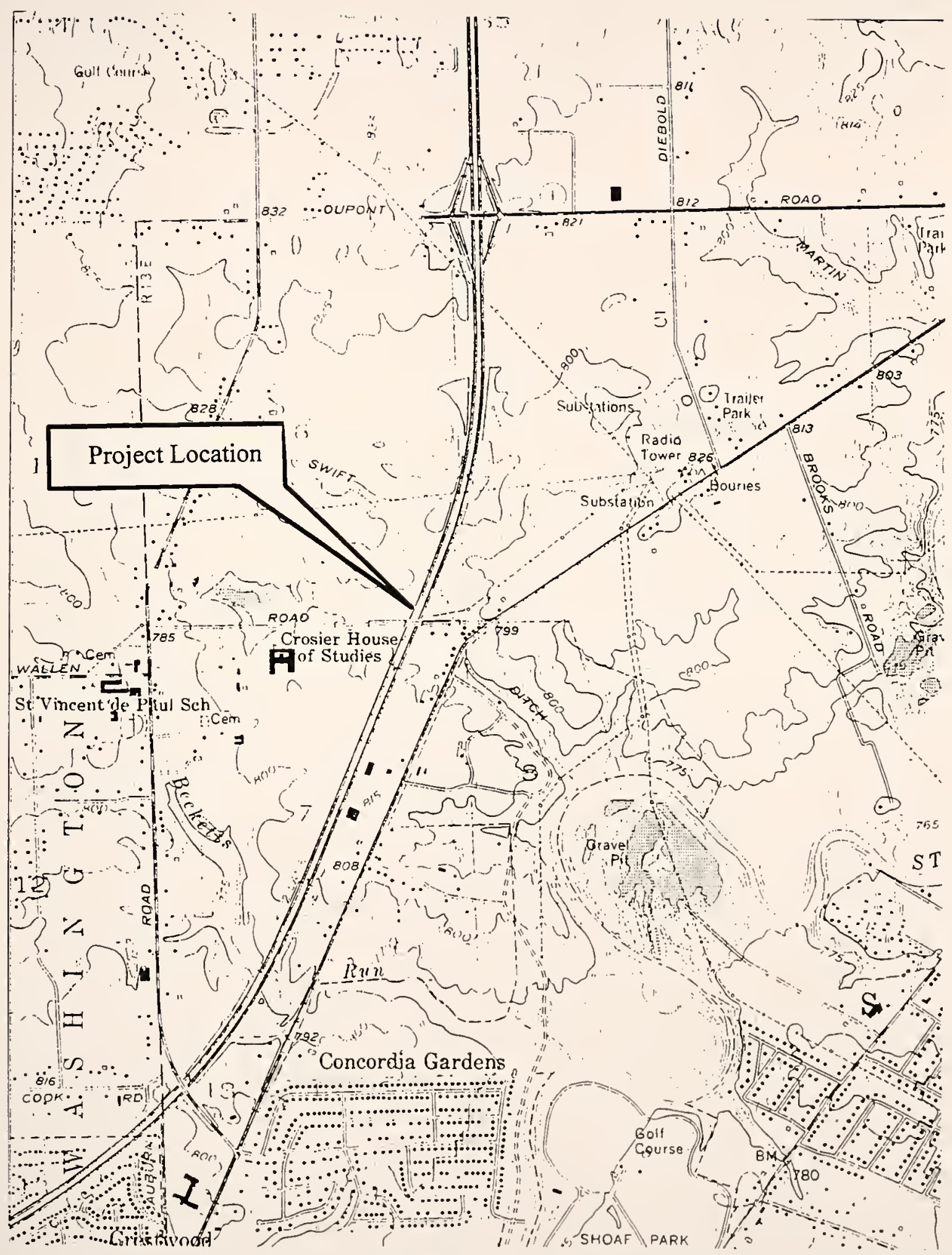

Figure 4.13 Site location map, Wallen Road, Allen Co., Fort Wayne District (Cedarville Quadrangle, Indiana) 
approximately $3 \mathrm{~m}$, with the widening equally divided between the left and right flanks of the approaches. Maximum sideslopes after widening are on the order of $2 \mathrm{H}: 1 \mathrm{~V}$.

Other then minor erosion, no distress of the roadway or embankment has been noted during site visits in Winter and Spring of 1997.

\section{Embankment Design and Construction Plans}

Design documents were not available for the sideslope steepening project suggesting that stability of the steepened embankment was not analyzed. Cross-sections for the proposed widening and steepening were provided in the plans. The existing and proposed sideslope geometries were indicated on the Construction Plans. The inclination of embankment sideslopes prior to steepening ranged from approximately $3.5 \mathrm{H}: 1 \mathrm{~V}$ to a maximum of $2 \mathrm{H}: 1 \mathrm{~V}$. After steepening, the inclination of the sideslopes was $2 \mathrm{H}: 1 \mathrm{~V}$.

Benches, excavated $1.5 \mathrm{~m}$ to $3 \mathrm{~m}$ wide with a backslope of $1 \mathrm{H}: 4 \mathrm{~V}$, were shown on the plans, and the cut and fill associated with the benches was indicated. The maximum thickness of the fill for steepening the sideslopes was approximately $0.75 \mathrm{~m}$.

\section{Construction Records}

As-built plans were reviewed and no changes to the initially proposed steepened slope geometry were noted. Available field compaction data was reviewed and is summarized in Table 4.9. The offset for the field density tests is referenced to line S-4-D of the project. As indicated in Table 4.9, the data provided represents compaction testing performed on three days over the duration of the project. The data for the east approach embankment indicate that the fill was placed in accordance with INDOT Standard Specifications (1993). All tests were within the specified water content range of -2 to +1 percent of the optimum moisture content (AASHTO T99, Method A). No test data were located for the west approach embankment. 
Table 4.9. Field compaction test data for Wallen Road Approaches, Allen Co., Fort Wayne District.

\begin{tabular}{lcrllll}
\hline Test No. ${ }^{(1)}$ & Sta. (ft.) & Date & Offset (ft) & OMC. (\%) & $\begin{array}{c}W_{\text {in-situ }} \\
(\%)\end{array}$ & $R C(\%)$ \\
& & & & & 16.7 & 99 \\
\hline $1(\mathrm{~N})$ & $17+00$ & $12 / 2 / 94$ & $25 \mathrm{LT}$ & 16.2 & 16.4 & 100 \\
$2(\mathrm{~N})$ & $17+08$ & $12 / 2 / 94$ & $35 \mathrm{LT}$ & 16.2 & 16.4 \\
$3(\mathrm{~N})$ & $16+90$ & $12 / 2 / 94$ & $40 \mathrm{LT}$ & 16.2 & 16.9 & 99.6 \\
$3221(\mathrm{~N})$ & $17+25$ & $6 / 19 / 95$ & $20 \mathrm{RT}$ & 14.3 & 15.1 & 101 \\
$3231(\mathrm{~N})$ & $18+00$ & $6 / 19 / 95$ & $20 \mathrm{LT}$ & 14.3 & 14.6 & 99.6 \\
$3241(\mathrm{~N})$ & $16+50$ & $6 / 19 / 95$ & $25 \mathrm{RT}$ & 16.2 & 15.9 & 100.3 \\
$3251(\mathrm{~N})$ & $17+00$ & $6 / 19 / 95$ & $25 \mathrm{LT}$ & 16.2 & 16.8 & 100.7 \\
$3261(\mathrm{~N})$ & $17+85$ & $6 / 20 / 95$ & $30 \mathrm{RT}$ & 16.2 & 15.7 & 101.1 \\
$3271(\mathrm{~N})$ & $18+55$ & $6 / 20 / 95$ & $30 \mathrm{LT}$ & 16.2 & 16.8 & 100.1 \\
\hline
\end{tabular}

Notes: (1) Sand-cone (S) or nuclear density gauge $(\mathrm{N})$.

Site Visit

Surface water is directed to the sideslope and no provisions for controlled surface water management exists (e.g., curbing, catch basins). An apparently healthy vegetative cover is present on the slope. No pavement distress was noted. Minor cracks in the fill at the slope crest were noted.

Hand auger borings were undertaken at this site. The original and new fill soils were granular in nature and of a dense consistency. The costs and disruption of traffic necessary for extensive excavation and in situ testing at the site was considered unwarranted because construction records, quality control test results and preliminary investigations indicated that the embankment was widened according to INDOT Standard Specifications and performance was satisfactory.

\subsubsection{U.S. 421 Wanatah, LaPorte Co., LaPorte District (B-21433)}

Work performed under Contract No. B-21433 comprised bridge deck reconstruction for a three span structure. The approach embankments were widened as part of the project. This structure carries U.S. 421, a two-lane road, over Conrail Railway and Bailey Road. The site location is presented in Figure 4.14. 
Plans indicate that the embankment flanks were widened a maximum of $2.4 \mathrm{~m}$. Maximum sideslopes after widening are on the order of $2 \mathrm{H}: 1 \mathrm{~V}$. No distress of the roadway or embankment has been reported.

\section{Embankment Design and Construction Plans}

Design documents were not available for the sideslope steepening project suggesting that the stability of the steepened embankment was not analyzed. Crosssections for the proposed widening were provided in the plans. The existing and proposed sideslope geometries were indicated on the Construction Plans. The inclination of embankment sideslopes prior to embankment widening was $2 \mathrm{H}: 1 \mathrm{~V}$ or shallower. After widening, the inclination of the sideslopes was $2 \mathrm{H}: 1 \mathrm{~V}$. Two to three meter wide benches with a vertical backslope were presented on the plans, and the cut and fill associated with the benches was indicated. The maximum thickness of the fill for widening the sideslopes was approximately $0.9 \mathrm{~m}$.

\section{Construction Records}

As-built plans were reviewed and no changes to the initially proposed steepened slope geometry were noted. Available field compaction data was reviewed and is summarized in Table 4.10. The offset for the field density tests is referenced to the center-line of the project. The data presented are for tests performed at or near the sideslope crest in areas widened; no test data was located which would indicate that compaction tests were performed down slope of the crest. The data indicates that fill placed met density requirements (INDOT 1993); however, none of the test were within the specified water content range of -2 to +1 percent of the optimum moisture content (AASHTO T99, Method A).

\section{Site Visit}

Surface water from the roadway is directed to concrete channels on the sideslopes A healthy vegetative cover was present on the slope with the exception of the northwest slope where bare spots were noted. A mulch blanket appears to have been used to assist in establishing vegetation, as the mesh is still visible on the sideslope. No pavement distress was apparent. 


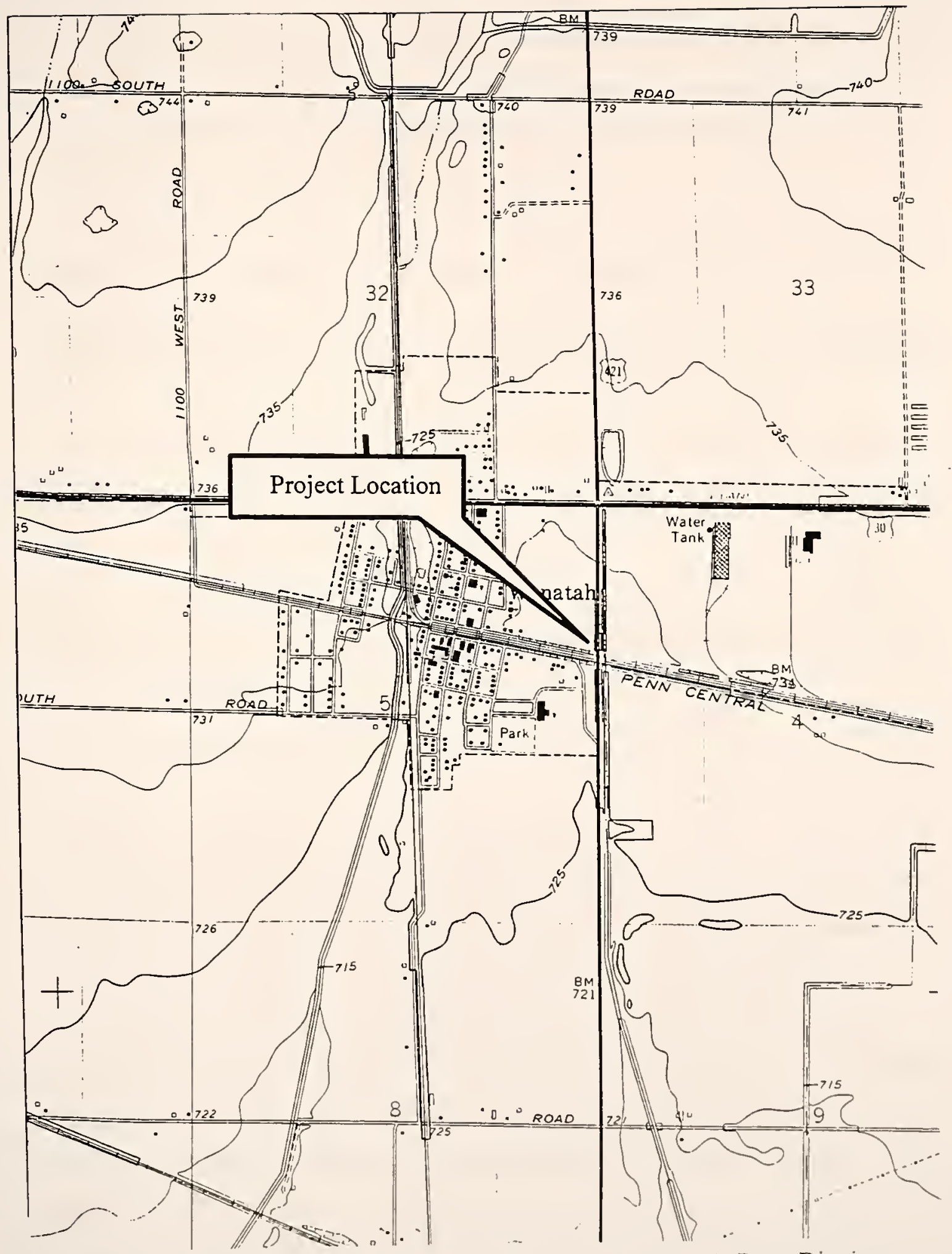

Figure 4.14. Site location map, U.S. 421 Wanatah, LaPorte Co., LaPorte District (Wanatah Quadrangle, Indiana) 
Hand auger borings were used to perform a preliminary subsurface investigation of the side slopes. The auger borings indicated that the new fill material was in a compact condition. Based on the experience gained to date, a more extensive excavation of the stable slopes was considered unwarranted.

Table 4.10. Field compaction test data for U.S. 421 Wanatah, LaPorte Co., LaPorte District.

\begin{tabular}{lccclll}
\hline Test No. $^{(1)}$ & Sta. (ft.) & Date & Offset (ft) & $\begin{array}{c}\text { OMC } \\
(\%)\end{array}$ & $\begin{array}{c}\mathrm{w}_{\text {in }- \text { silu }} \\
(\%)\end{array}$ & RC (\%) \\
\hline $3(\mathrm{~N})$ & $300+00$ & $5 / 15 / 95$ & $22 \mathrm{RT}$ & 11.9 & 7.5 & 103.3 \\
$6(\mathrm{~N})$ & $302+00$ & $5 / 19 / 95$ & $25 \mathrm{RT}$ & 11.9 & 9.4 & 101.0 \\
$2(\mathrm{~N})$ & $311+00$ & $6 / 30 / 95$ & $20 \mathrm{LT}$ & 8.5 & 15.5 & 95.6 \\
$6(\mathrm{~N})$ & $301+00$ & $7 / 6 / 95$ & $21 \mathrm{LT}$ & 11.9 & 7.6 & 102.8 \\
\hline
\end{tabular}

Notes: (1) Letter following test number indicates whether the density was determined using a sand-cone $(S)$ or nuclear density gauge $(N)$.

(2) Relative compaction is equal to the field dry density divided by the maximum dry density for the soil.

\subsection{State Road 1, St. Leon, Dearborn Co., R-20879}

During 1997 a slope failure occurred in an embankment supporting SR 1 in St.

Leon, Dearborn County, Indiana. Although the failure occurred in an embankment that was not "widened," the failure was investigated in order to provide INDOT with information that would be used in developing a plan for repair. The mechanism attributed to the failure at St. Leon differed from that of the failed widened embankments in that ground water seepage across the embankment reduced the stability of the slope. A letter report outlining the interpreted failure mechanism is included in Appendix A of this report. 


\section{CHAPTER 5}

\section{SUMMARY AND CONCLUSSIONS}

\subsection{Discussion}

There are a number of factors that influence the ultimate stability of widened embankment slopes. These include: removal of vegetation and construction of benches in existing embankment; achieving adequate compaction and shear strength of fill soils; achieving compatibility in the permeability of fill materials; controlling surface water runoff; considering the ultimate ground water flow regime; and considering the required final inclination of the embankment slope. Although all of these factors can be related in some degree to the cases investigated, the overriding factor contributing to the failures appears to be a lack of appreciation of the potential for failure by the personnel involved.

For the failed sites, little, if any, documentation was available that would indicate that the stability of the final constructed slopes had been considered. In general, there was no construction or as built drawings of the embankment slopes, and few, if any, quality control tests were performed outside of the right-of-way. In all cases, the slopes would have been stable if the INDOT Standard Specifications had been followed. It appears that in most cases the parties involved felt that the volume of fill placed did not warrant the extensive earthwork that would have been necessary to meet the specifications. Therefore, educating both INDOT technical personnel and earthwork contractors regarding the potential for such failures to occur is viewed as crucial to the ultimate success of these types of projects.

\subsection{Grubbing and Benching}

Removal of existing vegetation and organic top soil is essential to obtain an adequate construction joint between the old and new fill, and to eliminate the potential for weak seams to develop by the decomposition of organic materials. Investigations of failures at R-20882 and R-19972 both showed that organic materials were present along portions of the interface between the old and new fill materials.

The construction of benches in existing embankment slopes is required to provide a good construction joint between old and new fill and to provide a horizontal surface on 
which to adequately compact horizontal lifts. The existing INDOT Standard Specifications require a minimum bench width of $3 \mathrm{~m}$ on all widened slopes steeper than 4V:1H. Presumably this requirement was developed to provide an adequate width for passage of conventional compaction equipment. Although this requirement is satisfactory in many instances, there are situations where this specification may not be appropriate.

For example, there are situations where failed slopes are repaired by excavation and replacement with limestone rip-rap. During construction, the design for repair may call for temporary slopes as steep as $1 \mathrm{~V}: 1 \mathrm{H}$. The construction of $3 \mathrm{~m}$ benches in the IV:1H temporary slope will lead to vertical, or near vertical, faces of $3 \mathrm{~m}$. This condition may not be stable for some fill soils even for temporary conditions. Therefore, a recommendation will be made to modify the INDOT Standard Specifications to limit the height of the vertical cut between benches. This approach is similar to that recommended by TRB - Guide to earthwork construction (1990).

\subsection{Compaction and Strength of Fill Soils}

Fill soils are compacted in place to improve strength and control deformations. Existing INDOT Standard Specification for compacted fill calls for a minimum dry density equal to or greater than $95 \%$ of the maximum dry density achieved in the standard Proctor test (AASHTO T99) and a range of water content of $-2 \%$ to $+1 \%$ of the optimum for this test. These specifications are adequate and appropriate for soils compacted in the construction of widened embankments. Compaction to water contents near optimum will minimize the volume change and strength reduction that will occur due to changes in water content during the life of the structure. The density criterion will lead to adequate strength for lower plasticity soils at embankment slopes of $2 \mathrm{H}: 1 \mathrm{~V}$ or less. However, flatter slopes will be necessary for soils of higher plasticity, as outlined in a later section of this report.

When the extent of embankment widening is relatively minor, the width of the widened zone may be less than the width of conventional compaction equipment, particularly when the elevation nears the embankment crest. To achieve adequate compaction under these conditions it may be necessary to place and compact lifts of 
sufficient width to use conventional equipment. Subsequently, the embankment slopes can be graded to the desired slope with construction equipment such as a bulldozer.

\subsection{Compatibility in the Permeability of Fill Soils}

Consideration must be given to the relative permeability of the original embankment soil and the soil used to widen the embankment. If the new fill soil has substantially greater permeability than the original embankment soil, rainwater can infiltrate the surficial soils and become perched on the existing fill soils. This process can lead to softening and reduction in shear strength.

Conversely, if there is lateral flow of groundwater through the embankment, placement of less permeable fill soils on the slopes during widening may trap groundwater within the embankment. This may substantially change the groundwater level within the embankment and lead to a reduction in stability due to a reduction in shear resistance, and an increase in seepage stresses. Accordingly, the existing embankment soil and the future groundwater flow regime must be considered when selecting a compatible fill soil.

For conditions where the existing and new embankment soils are of similar classification (Liquid Limit \pm 5 , Plasticity Index \pm 5 ), and where lateral groundwater flow through the embankment is expected to be minor, the following approach may be considered in lieu of detailed analyses as illustrated in Figure 5.1:

1. Construct benches with adequate grade to induce lateral flow of any infiltration that encounters a less permeable interface, and thereby, minimize perched water at the interface between materials.

2. Install a perforated drain along the vertical cut of the first bench located outside of the pavement edge. The drain should be covered with an appropriate filter fabric that is compatible with the embankment soil type, and be outfitted with protected outlets at appropriate intervals along the length of the embankment.

\subsection{Controlling Surface Water Runoff}

The use of curbs has decreased in new construction along the highways. The use of curbs has important benefits from an embankment stability standpoint because they 

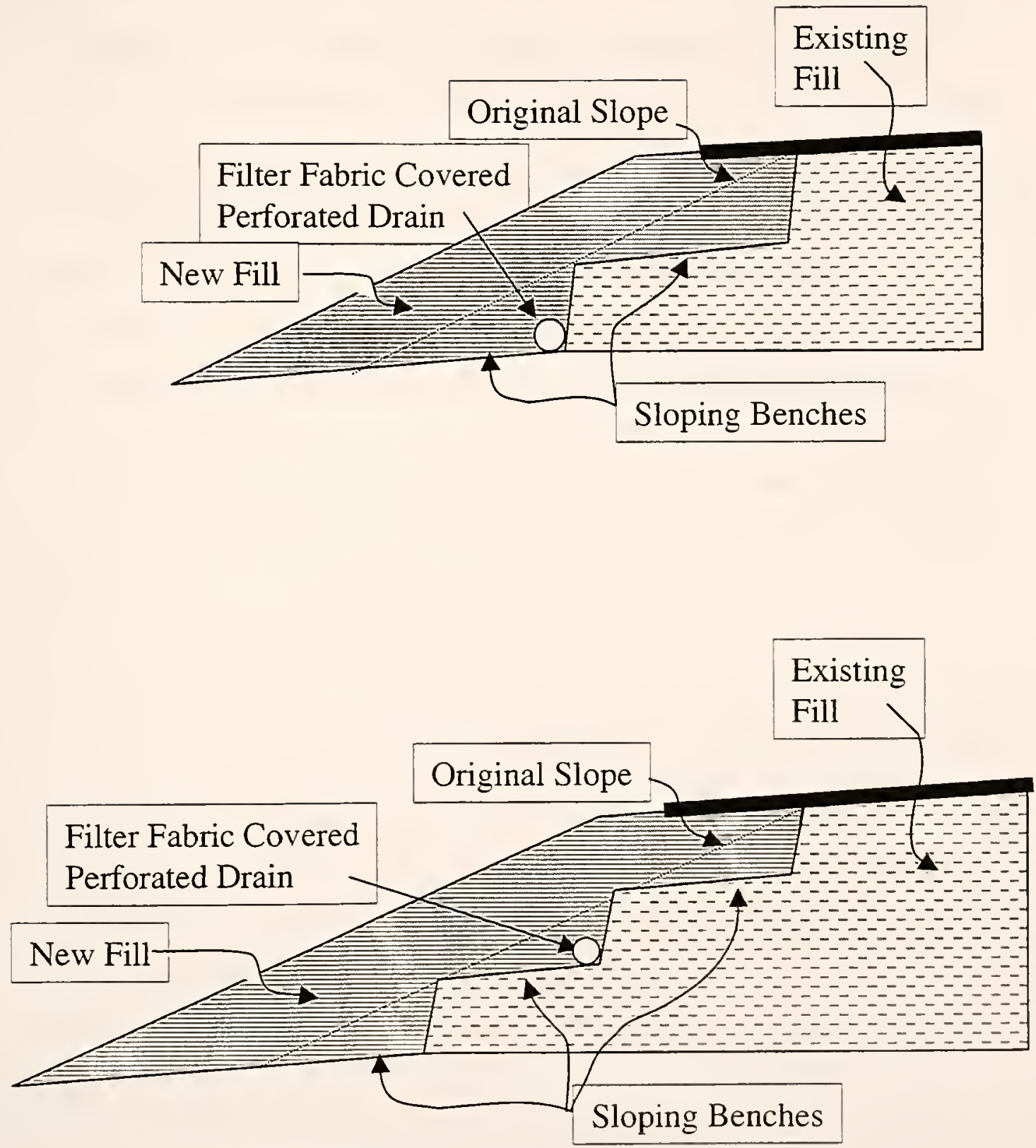

Figure 5.1. Schematics of bench inclination and drain placement illustrating drain located along vertical cut on first bench outside of pavement edge. 
control the flow of runoff from the road surface in a prescribed manner. The absence of curbs allows runoff to flow down the embankment slopes in an uncontrolled manner. This can lead to erosion of the embankment and increases in water content of the compacted soils, which often leads to greater incidences of surface sloughing. From an embankment stability standpoint it is desirable to have well designed systems for controlling the transmission of rainwater runoff away from the embankment slopes.

\subsection{Considering the Presence and Flow of Groundwater within the Embankment}

There are circumstances where the groundwater regime may substantially reduce embankment stability. This is illustrated by the embankment supporting SR 1 near St. Leon described in Section 4.4 and in Appendix A. If groundwater will be present within an embankment, the influence on stability must be considered during embankment design. Although rules-of-thumb are adequately used for many roadway embankment slopes, the presence of groundwater flow through an embankment warrants a more complete design including performing site specific stability analysis to account for seepage forces.

\subsection{Slope Inclination}

A general rule of thumb of $2 \mathrm{H}: 1 \mathrm{~V}$ is often used to define the limiting safe slope inclination for compacted soils. This inclination was consistent among the survey respondents from other state departments of transportation throughout the US as outlined in Chapter 3. However, there are soil types that are used occasionally in embankment construction for which this inclination may be too steep. In general, the effective stress friction angle of a soil decreases with increasing plasticity (Mitchell, 1974). Accordingly, soils possessing higher plasticity should be constructed at flatter slopes to provide adequate margins of safety.

The data from Mitchell (1974) were used to develop a simple relationship between plasticity index and slope inclination that is recommended for soils otherwise compacted according to the INDOT Standard Specifications. The relationship is provided in both graphical (Figure 5.2) and tabular (Table 5.1) formats. These recommendations were developed assuming prompt development of vegetative cover and controlled transmission of surface water runoff. Moreover, the slope inclinations 


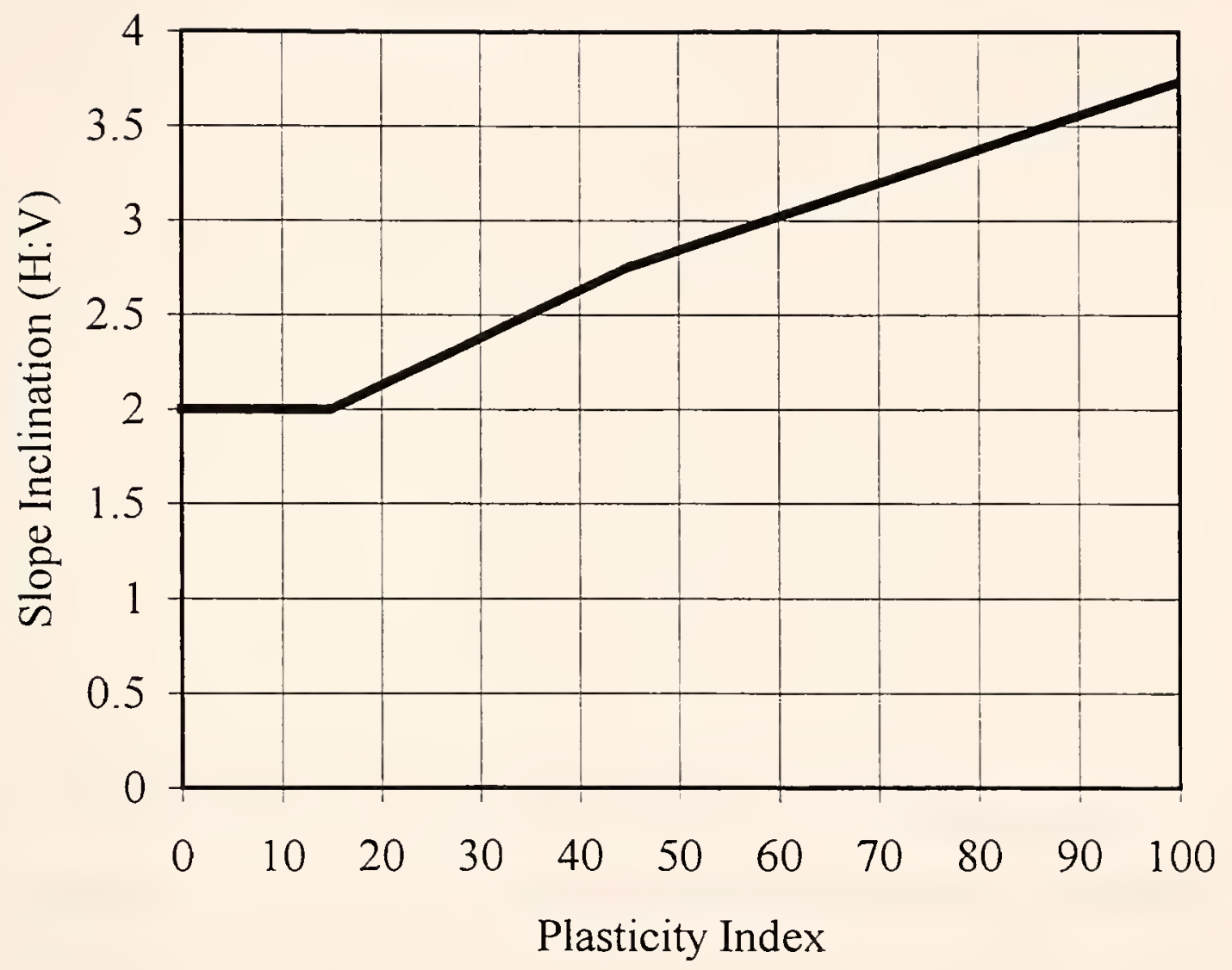

Figure 5.2 Recommended slope inclination as a function of plasticity 
recommended are not applicable if there is a potential for groundwater movements within the embankment. It is believed that steeper slopes than those recommended here may be adequate at some sites, however, this would require documentation from a detailed stability analysis using appropriate strength parameters for the specific embankment soils that will be used in construction.

Table 5.1 Recommended slope inclinations as a function of fill plasticity.

\begin{tabular}{|c|c|}
\hline $\begin{array}{c}\text { Plasticity } \\
\text { Index } \\
(\%)\end{array}$ & $\begin{array}{c}\text { Slope } \\
\text { Inclination } \\
(\mathrm{H}: \mathrm{V})\end{array}$ \\
\hline $0-20$ & 2 \\
\hline $21-25$ & 2.25 \\
\hline $26-35$ & 2.5 \\
\hline $36-45$ & 2.75 \\
\hline $46-55$ & 3 \\
\hline $56-70$ & 3.25 \\
\hline $71-85$ & 3.5 \\
\hline $86-100$ & 3.75 \\
\hline
\end{tabular}

\subsection{Recommended Changes to INDOT Standard Specifications}

The failure investigations indicated that the existing INDOT Standard Specifications were not followed at the sites where failure occurred, and that failures would not have occurred if the Standard Specifications had been followed. However, modifications can be made to the existing specifications that would improve embankment performance and the construction process, namely: the control of surface water runoff, compatibility of fill soils, and required bench geometry.

Controlled transmission of roadway surface water runoff is highly desirable from the standpoint of embankment maintenance and stability. Allowing the roadway runoff to flow down embankment slopes leads to development of erosion channels and increases in the degree of saturation of the compacted soils. Higher saturation reduces the stability of the slopes and often results in surface sloughing and possible loss of vegetative cover, particularly at early stages of growth. Curbs have traditionally been used to control runoff and direct flow to drains. Curbs, or an alternative method of controlling runoff, 
should be specified for all pavement systems on compacted embankments to improve stability and reduce maintenance costs.

The permeability of the fill used to widen the embankment should be approximately equal to or less than the permeability of the existing embankment. This requirement is needed to limit the potential for infiltrating water to become perched at the interface between the two embankment materials, which can lead to softening and strength reduction. This recommendation is not generally applicable when there will be groundwater flow through the embankment because it will alter the flow system, and could make the embankment less stable. For these conditions some type of drainage feature would need to be incorporated into the system. In any case, if there is the potential for groundwater flow through the roadway embankment, a detailed, site specific analysis is needed for the design of the embankment.

The current specification for bench width should include a limiting cut height of $1.5 \mathrm{~m}(5 \mathrm{ft})$, that is a bench width of $3 \mathrm{~m}$ is used unless it will lead to a cut height greater than $1.5 \mathrm{~m}$. For these cases, the bench width will be dictated by the maximum cut height. For example, if a slope that is currently $1.6 \mathrm{H}: 1 \mathrm{~V}$ is to be widened, the maximum bench width would be $2.4 \mathrm{~m}$. This criterion is needed to limit the potential for failure to occur in the vertical faces of the cut embankment under temporary conditions.

\subsection{Conclusions}

The results of the investigations for sites on I-69 in Madison and Grant County indicate that failure of these widened embankments resulted from sub-standard compaction of fill, and inadequate benching into the original embankment. Surface water infiltration from the roadway run-off contributed to the problem, possibly saturating and softening the soils. These conclusions confirm the responses of the survey conducted of Federal and State transportation agencies. Survey respondents indicated that successful widening requires:

- construction of benches into the original embankment;

- adequate compaction of fill; and,

- control of drainage. 
Construction Plans for successful projects (Wallen Road Bridge and U.S. 421 Wanatah) indicate that benching was performed even when the fills were minor, in some cases $0.3 \mathrm{~m}$ or less in thickness. The compaction data available for these projects, although considered insufficient, tends to indicate that soils were compacted when placed. Control of surface water run-off from the roadway may have contributed to the success of the U.S. 421 widening project.

Erodible, coarse-grained soils are not suitable for construction of widened embankments unless encased in less pervious soils. Erosion undercuts vegetation and permits infiltration of water into the slope. When the original embankment soils are of lower permeability, the infiltrating water can become perched and cause soils to soften and lose strength.

Sloughing is attributed to poor compaction and/or saturation of the slope. Better management of surface water run-off will reduce surficial erosion and sloughing; thereby, reducing slope maintenance costs. Where slopes are steeper then recommended in Figure 5.2 , or Table 5.1, site specific analysis is need to consider overall stability and sloughing stability of the slope.

Since the slope failures investigated would not have occurred if INDOT Standard Specifications were followed, it appears that the primary cause of failure is the lack of appreciation of the potential risk by the parties involved, both INDOT and construction personnel. Very little quality control testing was performed in the compacted soils comprising the widened embankment material even on the successful projects. No quality control testing was performed in the failed sections. One of the reasons for limited quality control testing on these projects may be limited availability of INDOT personnel for this purpose on smaller sized projects. It is imperative that the news from these failures, and all failures for that matter, be brought to the attention of INDOT engineers and technicians throughout the state so that they can become aware of the potential for failure, and prioritize their time for quality control testing when time is limited. 


\section{CHAPTER 6}

\section{RECOMMENDATIONS}

1. Modify the INDOT Standard Specifications to address the transmission of surface water runoff away from the embankment slopes.

2. Modify the INDOT Standard Specifications to limit the cut height of the embankment to $1.5 \mathrm{~m}$ during bench construction.

3. Modify the INDOT Standard Specifications such that in lieu of detailed analyses: 1) fill soils used in embankment widening are of similar classification (liquid limit \pm 5 , plasticity index \pm 5 ) as the existing embankment soils; 2) benches are constructed with adequate grade to induce lateral flow of any infiltrating water that encounters a less permeable interface; 3) a filter fabric covered perforated pipe is installed along the vertical cut of the first bench located outside of the pavement edge (Fig. 5.1) and day-lighted at appropriate intervals with proper protective covers. Also, course grained soils should be avoided because they have a tendency to erode and lose vegetative cover.

4. Modify the INDOT Standard Specifications such that site specific analysis and design of the embankment is required at all locations where there is the potential for significant groundwater flow within the embankment soils.

5. Modify the INDOT Standard Specifications to include the recommendations made in Figure 5.2 and Table 5.1 to limit the maximum slope inclination depending on the plasticity of the fill soils. Site specific testing and stability analysis should be performed if use of steeper slopes is desired.

6. Disseminate concise information regarding the cause of failures and recommended preventive measures to all INDOT engineers and technicians and to all related contractors so that the potential risk of failure is appreciated for specific types of projects and appropriate quality control testing can be made a priority. 


\section{ACKNOWLEDGEMENTS}

The authors are grateful to the Study Advisory Committee for their input throughout this project. Special thanks to Messrs. Athar Kahn and Nayyar Zia of INDOT Materials and Tests who recognized the need for, and initiated, this project. Their helpful guidance and practical insights were much appreciated. We would also like to thank Mr. Dan Chase of Materials and Tests for his assistance with inclinometer readings and interpretation at the St. Leon embankment failure. 


\section{REFERENCES}

Bromhead, E.N. (1986). The stability of slopes. Blackie \& Sons Ltd., London, England.

Casagrande, A. and Hirschfield, R.C. (1960). "Stress deformation and strength characteristics of a clay compacted at a constant dry unit weight." Research Conference on Shear Strength of Cohesive Soils, Soil Mech. and Found. Div., ASCE, Boulder Colorado, 359-417.

CEA (1991). Personal communication from Stephan F. Holder (CEA) to Firooz Zandi (INDOT), Dec. 17, 1991.

Day, R.W. (1992). "Effective cohesion for compacted clay." J. Geotech. Engrg., ASCE, 118(4), 611-619.

Day, R.W. (1994). "Surficial stability of compacted clay: case study." J. Geotech. Engrg., ASCE, 120(11), 1980-1990.

Day, R.W. and Axten, G.W. (1989). "Surficial stability of compacted clay slopes." J. Geotech. Engrg., ASCE, 115(4), 577-580.

Dept. of County Eng. - Facilities Bldg. And Safety Div. (1978). Minimum standards for slope stability analysis. County of Los Angeles, Los Angeles, California.

Duncan , J.M. (1996). "State of the art: limit equilibrium and finite-element analysis of slopes." J. Geotech. Engrg., ASCE, 122(7), 577-596.

Duncan, J.M., Buchignani, A.L., and De Wet, M. (1987). An engineering manual for slope stability studies. Virginia Tech, Blacksburg, Virginia. 
Indiana State Highway Commission (1971). Road design manual volume 1. Indiana State Highway Commission, Indianapolis, Indiana.

INDOT (1991). Inter-department communication from Firooz Zandi (INDOT and A.A. Khan (INDOT) to G. Henneke (INDOT), Attn.:D. Pluckebaum (INDOT), Dec. 20, 1991.

INDOT (1993). Standard Specifications 1993. Indiana Dept. of Transportation, Indianapolis, Indiana.

Lambe, T.W. (1958a). "The structure of compacted clay." J. Soil Mech. and Found. Div., ASCE, 84(SM2), 1654-1 to 1654-34.

Lambe, T.W. (1958b). "The engineering behavior of compacted clay." J. Soil Mech. and Found. Div., ASCE, 84(SM2), 1655-1 to 1655-35.

Lambe, T.W. and Whitman, R.V. (1969). Soil mechanics. John Wiley \& Sons, New York, New York.

Leonards, G.A. (1955). "Strength characteristics of compacted clays." Transactions, ASCE, 120, 1420-1454.

Mitchell, R.K. (1974). The Fundamental of Soil Behavior, John Wiley \& Sons, New York, New York, $1^{\text {st }}$ Edition.

Seed, H.B. and Chan, C.K. (1959). "Structure and strength characteristics of compacted clays." J. Soil Mech. and Found. Div., ASCE, 85(SM5), 87-128.

TRB (1990). State of the art report 8, guide to earthwork construction. Transportation Research Board, National research Council, Washington, D.C. 
Wu, T.H., Randolph, B.W., and Huang, C. (1993). "Stability of shale embankments." J. Geotech. Engrg., ASCE, 119(1), 127-146. 

